\title{
Some genetic factors of Parkinson's disease in the Hungarian population
}

\author{
Ph.D. thesis \\ Rita Maszlag-Török M.SC. \\ Graduate School of Clinical Medicine \\ Department of Neurology, Faculty of Medicine \\ Albert Szent-Györgyi Clinical Center, \\ University of Szeged
}

Supervisor: Péter Klivényi, MD, PhD, DSc

Szeged 
TABLE OF CONTENTS

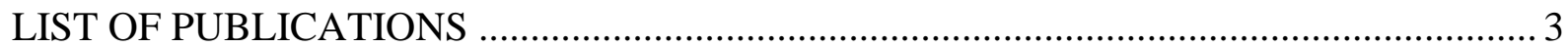

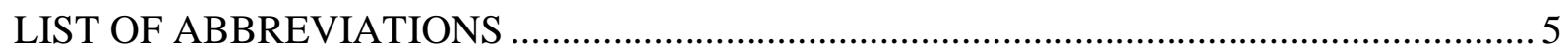

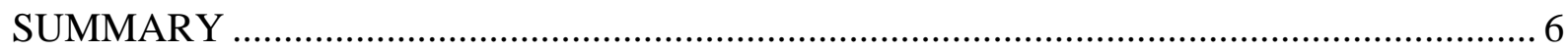

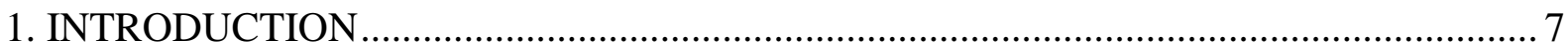

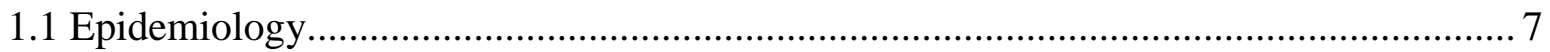

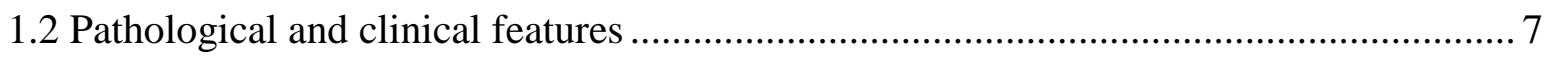

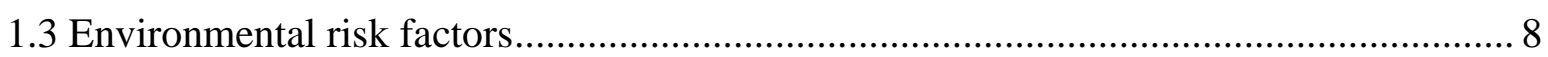

1.4 Genetics of Parkinson's disease .............................................................................. 8

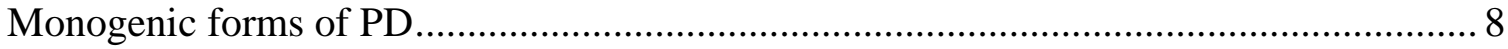

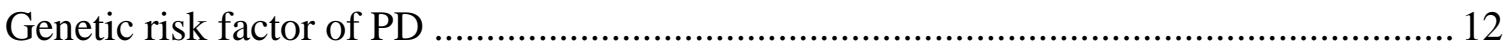

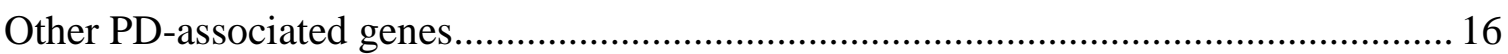

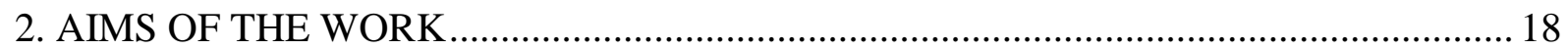

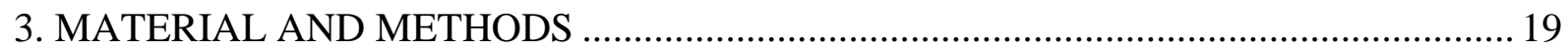

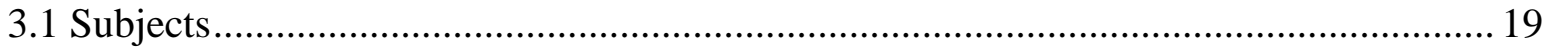

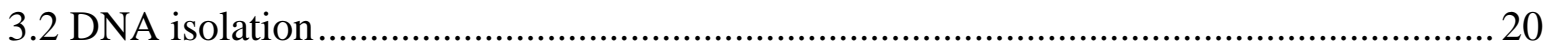

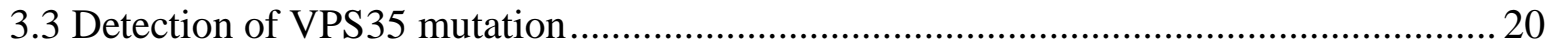

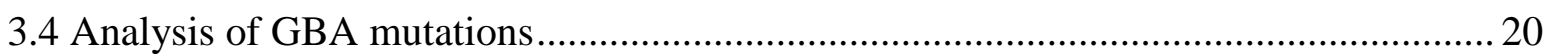

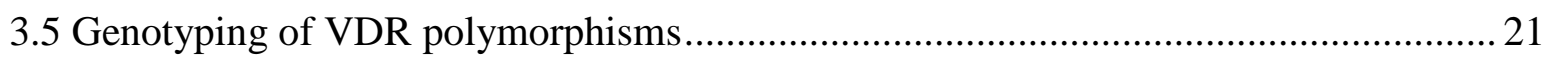

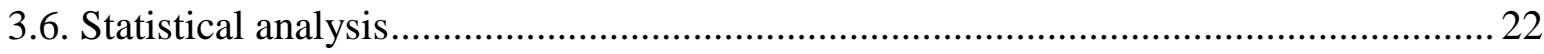

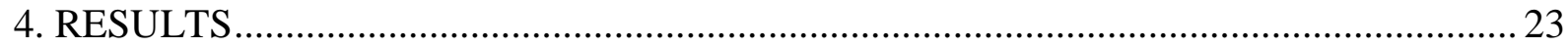

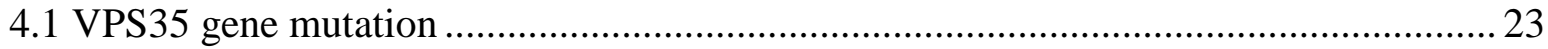

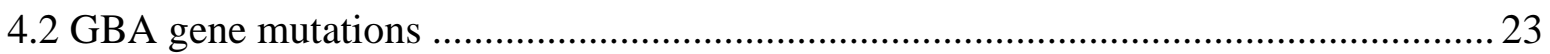

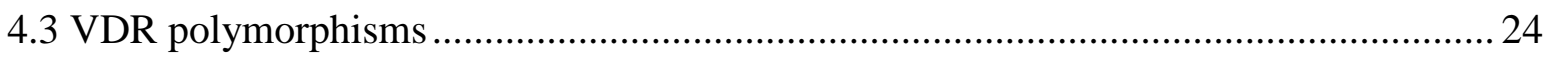

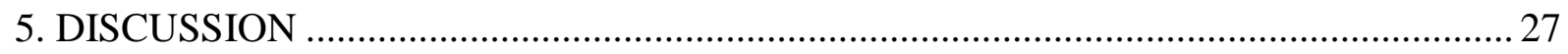

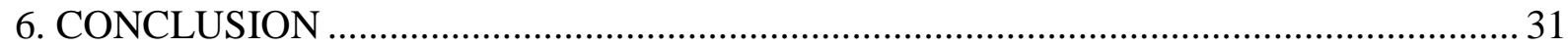

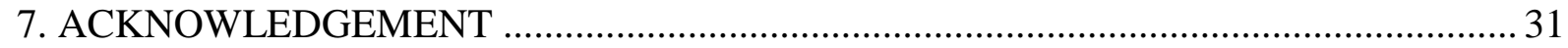

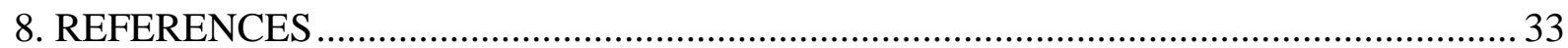




\section{LIST OF PUBLICATIONS}

Publications directly related to the subject of the dissertation

I. Török R, Török N, Szalardy L, Plangar I, Szolnoki Z, Somogyvari F, Vecsei L, Klivenyi P. Association of vitamin D receptor gene polymorphisms and Parkinson's disease in Hungarians. Neuroscience Letters 551: pp. 70-74. (2013)

IF: 2.055

II. Török R, Zadori D, Török N, Csility É, Vecsei L, Klivenyi P. An assessment of the frequency of mutations in the GBA and VPS35 genes in Hungarian patients with sporadic Parkinson's disease. Neuroscience Letters 610: pp. 135-138 (2016)

IF: 2.180

Cumulative impact factor of the publications directly related to the thesis: $\mathbf{4 . 2 3 5}$ 


\section{Publications not related to the subject of the dissertation}

1. Torok R, Salamon A, Sumegi E, Zadori D, Veres G, Molnar MF, Vecsei L, Klivenyi P. Effect of MPTP on mRNA expression of PGC-1 $\alpha$ in mouse brain. Brain Research 1660: pp. 20-26 (2017)

\section{IF:2.746}

2. Molnár MF, Török R, Szalárdy L, Sümegi E, Vécsei L, Klivényi P. High-dose 1,25dihydroxyvitamin D supplementation elongates the lifespan of Huntington's disease transgenic mice. Acta Neurobiolgiae Experimentalis 76: pp. 176-81 (2016)

IF:1.207

3. Szalardy L, Molnar M, Torok R, Zadori D, Kovacs GG, Vecsei L, Klivenyi P. Lack of age-related clinical progression in PGC-1 $\alpha$-deficient mice - implications for mitochondrial encephalopathies. Behavioural Brain Research 313: pp. 272-281(2016) IF: 3.002

4. Szalardy L, Molnar M, Torok R, Zadori D, Vecsei L, Klivenyi P, Liberski P. P, Kovacs G. G. Histopathological comparison of Kearns-Sayre syndrome and PGC-1 $\alpha$-deficient mice suggests a novel concept for vacuole formation in mitochondrial encephalopathy. Folia Neuropathologica 54: pp. 9-22 (2016)

IF: 1.568

5. Török N, Török R, Klivényi P, Engelhardt J, Vécsei L. Investigation of vitamin D receptor polymorphisms in amyotrophic lateral sclerosis. Acta Neurologica Scandinavica 133: pp. 302-308. (2016)

IF: $\mathbf{2 . 4 0}$

6. Török N, Török R, Szolnoki Z, Somogyvári F, Klivényi P, Vécsei L. The Genetic Link between Parkinson's Disease and the Kynurenine Pathway Is Still Missing. Parkinson's Disease. 2015;2015:474135. doi: 10.1155/2015/474135.

IF: 2.098

7. Veres G, Molnar M, Zadori D, Szentirmai M, Szalardy L, Torok R, Fazekas E, Ilisz I, Vecsei L, Klivenyi P. Central nervous system-specific alterations in the tryptophan metabolism in the 3-nitropropionic acid model of Huntington's disease. Pharmacology Biochemistry and Behavior 132: pp. 115-124. (2015)

IF: $\mathbf{2 . 8 2 0}$

8. Török R, Konya JA, Zadori D, Veres G, Szalardy L, Vecsei L, Klivenyi P. mRNA Expression Levels of PGC-1alpha in a Transgenic and a Toxin Model of Huntington's Disease. Cellular and Molecular Neurobiology 35: pp. 293-301. (2015)

IF: 2.201

9. Gajda Z, Torok R, Horvath Z, Szantai-Kis C, Orfi L, Keri G, Szente M. Protein kinase inhibitor as a potential candidate for epilepsy treatment. Epilepsia 52: pp. 579588. (2011)

IF: 3.961

Cumulative impact factor of the publications directly related to the thesis: $\mathbf{2 2 . 0 0 3}$ Total impact factor: $\mathbf{2 6 . 2 3 8}$ 


\section{LIST OF ABBREVIATIONS}

$1,25 \mathrm{OHD}$

25OHD

AAO

$\mathrm{AD}$

AR

CI

CNV

EOPD

GCase

GBA

GD

GWAS

LOPD

LRRK2

MAPT

MPTP

OR

PD

SN

SNCA

SPD

VDR

VPS35 1,25-dihydroxyvitamin D

25-hydroxyvitamin D

age at onset

autosomal dominant

autosomal recessive

confidence interval

copy number variant

early-onset Parkinson's disease

$\beta$-glucocerebrosidase enzyme

glucocerebrosidase

Gaucher's disease

genome-wide association study

late-onset Parkinson's disease

leucine-rich repeat kinase 2

microtubule-associated protein tau

1-methyl-4-phenyl-1,2,3,6-tetrahydropyridine

odds ratio

Parkinson's disease

substantia nigra

$\alpha$-synuclein

sporadic Parkinson's disease

vitamin D receptor

vacuolar protein sorting associated protein 35 


\section{SUMMARY}

Parkinson's disease (PD) is the second most common neurodegenerative disorder. Latest results from the literature suggest that genetic factors are involved in the pathogenesis of PD. Several mutations and polymorphisms in a number of genes have been provide to have an important role in the development of PD. The majority of PD casas are sporadic; only $15-20 \%$ of the cases are identified as familial.

The genetic causes and risk factors of PD may serve as important tools through which to attain a better understanding of the pathomechanism. However, the vast majority of PD is genetically complex, it is caused by the complex interaction of genetic variants in concert with environmental factors. Genome-wide association studies have been published numerous PD risk loci to date. Particular attention has recently been paid to genes of the vacuolar protein sorting-associated protein 35 (VPS35), the glucocerebrosidase (GBA) and the vitamin D receptor (VDR). The mutations of these genes were investigated in number of studies, but the results are controversial.

Therefore, in this work, we have examined the p.D620N mutation of the VPS35 gene, which is the only confirmed pathogenic VPS35 variant identified to date. Moreover, we have investigated the three most common mutations (p.L444P, p.N370S and p.R120W) of the GBA and the four most studied polymorphisms (FokI, BsmI, ApaI and TaqI) of VDR gene in Hungarian population.

Since a genetic background is presumed in the development of PD in some cases, it is important to investigate the different genetic factors in the various PD populations, which may permit the development of new therapeutic targets. 


\section{INTRODUCTION}

\subsection{Epidemiology}

Parkinson's disease (PD) was first described by James Parkinson in 1817 (Parkinson, 2002). Nowadays, it is the second most common neurodegenerative disorder after Alzheimer's disease. A meta-analysis revealed that the prevalence of PD is increased with age: $0.05 \%$ in individuals 40 to 49 years; $0.1 \%$ in individuals 50 to 59 years; $0.4 \%$ in individuals 60 to 69 years; $1.1 \%$ in individuals 70 to 79 years; and 1.9\% in individuals over age 80 (Pringsheim et al., 2014). In the 50 to 59 age group, males had a significant increased prevalence of PD compared to females, while in the other age groups, only a slight male dominance of PD was observed (Pringsheim et al., 2014).

Moreover, it is well known that PD occurs in all ethnic groups around the world and shows geographic variability (Zhang and Roman, 1993). Individuals in Asia had a significantly lower prevalence of PD compared to individuals in Europe, North America and Australia. The reason of geographic variation in the occurrence of PD is unknown, but genetic or environmental susceptibilities might explain these findings (Muangpaisan et al., 2011).

\subsection{Pathological and clinical features}

The most prominent neuropathological features of PD are the loss of dopaminergic neurons in the substantia nigra (SN) pars compacta and the presence of Lewy bodies, which are accumulated and aggregated alpha-synuclein (SNCA) inclusions in the cytoplasm of the surviving neurons. The classical motor symptoms like bradykinesia, rigidity, resting tremor and late postural instability result directly or indirectly from the dopaminergic deficiency. Additionally, many other neuronal pathways not directly involved in motor function (such as the noradrenergic locus coeruleus, the serotonergic raphe nuclei, and the cholinergic nucleus basalis of Meynert) also show the sign of degeneration (Jellinger, 1991). Therefore, non-motor symptoms also appear, like dementia, depression, anxiety and autonomic dysfunctions (Pfeiffer, 2016).

Although the precise pathomechanism of PD is still not fully understood, several molecular mechanisms of neuronal death in PD pathogenesis have been described including mitochondrial dysfunction, oxidative stress, microglia activation and inflammation. With regard to aetiological background, the most common concepts is that PD may result from complex 
interaction between environmental factors, genetic background, and aging (Burbulla and Kruger, 2011).

\subsection{Environmental risk factors}

Environmental exposures seem to play an important role in the development of PD. The discovery of the 1-methyl-4-phenyl-1,2,3,6-tetrahydropyridine (MPTP) in 1983 provided the first proof that an environmental toxin could lead to parkinsonism in human (Langston et al., 1983). This toxin can cause the selective damage of the cells in the SN by inhibition of mitochondrial complex I (Singer and Ramsay, 1990). Moreover, epidemiological studies provided evidence that the chronic exposure of pesticides, metals and solvents could increase the risk of developing PD (Gorell et al., 1998, Jankovic, 2005, Gatto et al., 2009). However, there is no conclusive evidence proving that any environmental toxin causes PD. Smoking has been inversely associated with susceptibility to PD, but smoking does not appear to have any effect on disease progression or prevention (Gorell et al., 1999, Alves et al., 2004).

\subsection{Genetics of Parkinson's disease}

\section{Monogenic forms of PD}

Parkinson's disease is classified into familiar and sporadic groups. The majority of PD cases are sporadic; only $15-20 \%$ of the cases are identified as familial. Nevertheless, in most populations up to 5\%-10\% of patients carry mutations in monogenic forms. So far, 21 loci have been identified in familial PD (Table 1.). The PARK designations refer to monogenic forms of autosomal dominant PD (PARK1/4, PARK3, PARK5, PARK8, PARK11, PARK13, PARK17, PARK18, and PARK21), and autosomal recessive PD (PARK2, PARK6, PARK7, PARK9, PARK14, PARK15, PARK19 and PARK20) (Coppede, 2012).

The relationship between mutations in several of these genes and PD is uncertain. However, several genes suggest that abnormal handling of misfolded proteins by the ubiquitin-proteasome and autophagy-lysosomal system, increased oxidative stress, mitochondrial and lysosomal dysfunction contribute to PD development (Kalinderi et al., 2016). 


\begin{tabular}{|c|c|c|c|c|}
\hline Locus & Gene & $\begin{array}{l}\text { Inherit. } \\
\text { type }\end{array}$ & Mutation & Disorder \\
\hline $\begin{array}{l}\text { PARK1/4 } \\
(4 q 21-22)\end{array}$ & SNCA & $\mathrm{AD}$ & $\begin{array}{l}\text { p.A30P, p.E46K and } \\
\text { pA53T substitution and } \\
\text { CNVs }\end{array}$ & $\begin{array}{l}\text { EOPD, progressive, } \\
\text { levodopa responsive } \\
\text { parkinsonism with } \\
\text { dementia }\end{array}$ \\
\hline $\begin{array}{l}\text { PARK2 } \\
(6 q 25.2- \\
27)\end{array}$ & Parkin & AR & $\begin{array}{l}\text { Homozygous/ } \\
\text { compound } \\
\text { heterozygous missense } \\
(>57) \text { and exonic CNVs }\end{array}$ & $\begin{array}{l}\text { EOPD, slow progression, } \\
\text { responsive to levodopa, } \\
\text { with early dyskinesias }\end{array}$ \\
\hline $\begin{array}{l}\text { PARK3 } \\
(2 q 13)\end{array}$ & Unknown & $\mathrm{AD}$ & N/A & Classical PD \\
\hline $\begin{array}{l}\text { PARK5 } \\
\text { (4p13) }\end{array}$ & UCHL1 & $\mathrm{AD}$ & p.I93M substitution & Classical PD \\
\hline $\begin{array}{l}\text { PARK6 } \\
(1 \mathrm{p35}-36)\end{array}$ & PINK1 & AR & $\begin{array}{l}\text { Missense and exonic } \\
\text { CNVs }\end{array}$ & $\begin{array}{l}\text { EOPD, slow progression, } \\
\text { responsive to levodopa, } \\
\text { some with dyskinesias }\end{array}$ \\
\hline $\begin{array}{l}\text { PARK7 } \\
(1 \mathbf{1 p 3 6 )}\end{array}$ & DJ-1 & AR & $\begin{array}{l}\text { Homozygous missense } \\
\text { and deletion } \\
\text { (delEX1-5) mutations, } \\
\text { compound } \\
\text { heterozygotes }\end{array}$ & $\begin{array}{l}\text { EOPD, slow progression, } \\
\text { levodopa responsive }\end{array}$ \\
\hline $\begin{array}{l}\text { PARK8 } \\
(12 q 12)\end{array}$ & LRRK2 & $\mathrm{AD}$ & $\begin{array}{l}\text { Several mutations, } \\
\text { Substitutions; } \\
\text { p.R1441C/G, } \\
\text { p.Y1699C, p.G2019S } \\
\text { and p.I2020T }\end{array}$ & $\begin{array}{l}\text { Classical PD, } \\
\text { predominantly levodopa } \\
\text { responsive }\end{array}$ \\
\hline $\begin{array}{l}\text { PARK9 } \\
(1 \mathrm{p} 36)\end{array}$ & ATP13A2 & AR & $\begin{array}{l}\text { Homozygous/ } \\
\text { compound } \\
\text { heterozygous CNVs }\end{array}$ & $\begin{array}{l}\text { Kufor-Rakeb syndrome; } \\
\text { atypical PD with } \\
\text { dementia, spasticity, and } \\
\text { gaze palsy }\end{array}$ \\
\hline $\begin{array}{l}\text { PARK10 } \\
(1 \mathrm{p} 32)\end{array}$ & Unknown & N/A & N/A & Classical PD \\
\hline $\begin{array}{l}\text { PARK11 } \\
(2 q 36-37)\end{array}$ & GIGYF2? & $\mathrm{AD}$ & Missense mutation & LOPD \\
\hline $\begin{array}{l}\text { PARK12 } \\
\text { (Xq21-25) }\end{array}$ & Unknown & $\begin{array}{l}\mathrm{X}- \\
\text { linked }\end{array}$ & N/A & Classical PD \\
\hline $\begin{array}{l}\text { PARK13 } \\
(2 q 12)\end{array}$ & OMI/HTRA2 & $\mathrm{AD}$ & p.G399S & Classical PD \\
\hline $\begin{array}{l}\text { PARK14 } \\
(22 q 13.1)\end{array}$ & PLA2G6 & AR & $\begin{array}{l}\text { Homozygous/ } \\
\text { compound } \\
\text { heterozygous }\end{array}$ & $\begin{array}{l}\text { EOPD with dyskinesias, } \\
\text { levodopa responsive }\end{array}$ \\
\hline $\begin{array}{l}\text { PARK15 } \\
(22 q 12- \\
\text { 13) }\end{array}$ & FBXO7 & AR & $\begin{array}{l}\text { Homozygote and } \\
\text { compound heterozygote } \\
\text { mutations }\end{array}$ & $\begin{array}{l}\text { Juvenile parkinsonism, } \\
\text { severe phenotype with } \\
\text { spasticity and dementia }\end{array}$ \\
\hline $\begin{array}{l}\text { PARK16 } \\
(1 q 32)\end{array}$ & Unknown & N/A & N/A & Classical PD \\
\hline $\begin{array}{l}\text { PARK17 } \\
(16 q 11.2)\end{array}$ & VPS35 & $\mathrm{AD}$ & p.D620N & Classical PD \\
\hline
\end{tabular}




\begin{tabular}{lllll}
\hline $\begin{array}{l}\text { PARK18 } \\
\text { (3q27.1) }\end{array}$ & EIF4G1 & AD & Missense mutations & Classical PD \\
\hline $\begin{array}{l}\text { PARK19 } \\
(\mathbf{1 p 3 1 . 3 )}\end{array}$ & $\begin{array}{l}\text { DNAJC6 } \\
\text { (auxilin) }\end{array}$ & AR & $\begin{array}{l}\text { Homozygote/ } \\
\text { compound heterozygote } \\
\text { mutation }\end{array}$ & Juvenile parkinsonism \\
\hline $\begin{array}{l}\text { PARK20 } \\
\mathbf{( 2 1 q 2 2 . 1 1 )}\end{array}$ & $\begin{array}{l}\text { SYNJ1 } \\
\text { (synaptojanin }\end{array}$ & AR & $\begin{array}{l}\text { Homozygote missense } \\
\text { mutation: p.R258Q }\end{array}$ & $\begin{array}{l}\text { Juvenile parkinsonism } \\
\text { with mental retardation }\end{array}$ \\
\hline $\begin{array}{l}\text { PARK21 } \\
\text { (3q22.1) }\end{array}$ & DNAJC13 & AD & p.N855S & LOPD \\
\hline
\end{tabular}

Table 1. PARK loci and genes associated with familial forms of PD

AD: autosomal dominant, AR: autosomal recessive, CNV: copy number variant, EOPD: earlyonset Parkinson's disease, LOPD: late-onset Parkinson's disease

\section{PARK1/4: $\alpha$-synuclein (SNCA)}

SNCA was discovered first to play a role in PD. In 1996, a genome wide linkage analysis mapped the PARK1 locus on chromosome 4q21 (Polymeropoulos et al., 1996). A year later, the first missense mutation (p.A53T) in the SNCA gene was identified as the cause of disease in Italian and Greek families with autosomal dominant PD (Polymeropoulos et al., 1997). Then, two additional rare missense mutations, p.A30P (c.88C $>\mathrm{G})$ and p.E46K (c.188G>A) were discovered in German and Spanish families respectively (Kruger et al., 1998, Zarranz et al., 2004). The three missense mutations in the SNCA gene alter the function of the protein and are believed to promote aggregation of the protein (Conway et al., 1998, Choi et al., 2004).

Besides these mutations, multiplication of the SNCA gene was also associated with familial cases of PD. SNCA duplications found in French families with milder clinical phenotype (Chartier-Harlin et al., 2004), in Japanese families and in three apparently sporadic PD patients from Korea (Nishioka et al., 2006, Ahn et al., 2008). SNCA triplications were identified in an American and Swedish-American patients (Farrer et al., 2004). SNCA multiplications are associated with increased $\alpha$-synuclein mRNA and protein in brain tissues (Farrer et al., 2004).

\section{PARK2: Parkin}

One year later after the discovery of $S N C A$, PARK2 locus was mapped to chromosome 6q2527 in Japanese family with autosomal recessive juvenile parkinsonism and the causative gene was identified as parkin (Kitada et al., 1998). Until now, numerous mutation have been published including point mutations, frameshift mutations, deletions, and multiplication of exons (Abbas et al., 1999, Hedrich et al., 2004). Parkin gene mutations are there the most common autosomal recessive mutations in the early onset PD. Parkin mutations have been 
identified in up to $50 \%$ of familial cases and in $18 \%$ of sporadic diseases (Schulte and Gasser, 2011).

Parkin is an E3 ubiquitin ligase. The mutant parkin causes a loss of normal E3 ligase activity leading to the accumulation of its substrates such as synphilin-1, synaptotagmin XI and Hsp70 (Shimura et al., 2000).

\section{PARK6: PTEN-induced kinase 1 (PINK1)}

In 2001, PARK6 locus was mapped on chromosome 1p35-36 in an Italian family with autosomal recessively inherited form of PD (Valente et al., 2001). Later, two homozygous point mutations (p.G309A and p.W437X) in the PINK1 gene were described in two families with early onset and slowly progressive PD (Valente et al., 2004). Today, more than 25 pathogenic mutations were identified already. The frequency of these mutations in PD patients is between $0.5 \%$ and $9 \%$ in various populations (Bonifati et al., 2005, Ibanez et al., 2006).

PINK1 is a mitochondrial kinase, which protects cells against oxidative stress induced apoptosis (Valente et al., 2004). Mutant PINK1 can lead to apoptosis of dopaminergic cells (Zhou et al., 2014).

\section{PARK7: DJ-1}

PARK7 locus was identified on chromosome 1p36. In 2003, a large deletion (delEX1-5) and a missense mutation (p.L166P) were reported in two families, leading to identification of DJ-1 gene as a causative gene for familial PD with recessive inheritance (van Duijn et al., 2001, Bonifati et al., 2002). Mutations in DJ-1 are responsible for 1-2\% of EOPD cases (Bonifati et al., 2003). DJ-1 is a multifunctional protein that participates in antioxidative protection and mitochondrial function (Ariga et al., 2013).

\section{PARK8: Leucine-rich repeat kinase 2 (LRRK2)}

PARK8 locus was mapped on chromosome 12 in a Japanese family with ADPD in 2002 (Funayama et al., 2002). The gene has 51 exons encode a large 2527 amino acid protein, which contains several domains. In 2004, 2 groups identified the discovery of mutations in LRRK2 gene. It has been reported that mutations in the different domains results in variable pathological changes (Zimprich et al., 2004). Since then, many missense mutations have been identified in LRRK2, but the pathogenicity is only clearly for seven of them (Healy et al., 2008). The common feature is neuronal loss and gliosis in the SN. The LRRK2 mutations constitute around 
$10 \%$ of the familial PD cases, with a clear autosomal dominant inheritance pattern (Healy et al., 2008).

\section{PARK17: vacuolar protein sorting associated protein 35 (VPS35)}

The VPS35 gene, which is involved in the development of many neurodegenerative diseases, including Alzheimer's disease and PD (Small et al., 2005, Deng et al., 2013), is localized to 16q11.2, and various mutations have been reported in it (Zhang et al., 2000). The gene encodes the vacuolar sorting protein homolog, which is a key component of the retromer complex and is involved in the retrograde transport of proteins from endosomes to the trans-Golgi network (Bonifacino and Hurley, 2008).

Amongst the mutations of the VPS35 gene, the p.D620N missense mutation has recently been reported to be pathogenic for PD (Vilarino-Guell et al., 2011, Zimprich et al., 2011, Williams et al., 2017), mainly in the autosomal dominantly inherited cases, but it has additionally been detected in some sporadic PD cases (Vilarino-Guell et al., 2011, Zimprich et al., 2011, Ando et al., 2012, Kumar et al., 2012, Lesage et al., 2012, Sheerin et al., 2012). The p.D620N mutation was found in 5 familial and 2 sporadic cases (Sharma et al., 2012). In contrast, other studies suggest that there is no such mutation in SPD in the Caucasian population (Kumar et al., 2012, Sheerin et al., 2012). The mutation carriers have been estimated to account for less than $1 \%$ of the PD population. Additional rare VPS35 variants (i.e. P316S, R524W, I560T, H599R and M607V) may also be linked to PD, although their pathogenicity remains unclear (Sharma et al., 2012, Deng et al., 2013).

\section{Genetic risk factor of PD}

Monogenic forms represent less than $10 \%$ of PD in most populations. Apart from monogenic forms of PD, genetic risk factors would stand out as the cause of disease as well, affecting the age at onset and progression, possibly in combination with environmental factors. Genomewide association studies (GWAS) have focused on identifying genetic variability serving risk for PD.

Among the identified risk factors for PD, consistent associations have been demonstrated for SNCA, LRRK2 and MAPT (Labbe and Ross, 2014). In addition, heterozygous mutations in the GBA gene have been validated as a genetic susceptibility factor for PD (Kalinderi et al., 2016). 


\section{SNCA}

The role of genetic variants in SNCA gene have been identified in number of studies from various populations. Point mutations and CNVs are rare in sporadic cases (Johnson et al., 2004). However, genetic polymorphisms in the promoter and toward the 3 ' end of the gene was associated with sporadic PD (Pals et al., 2004, Mueller et al., 2005). In addition, an allele length variation (SNCA Rep1) has also been associated with an increased risk for PD (Maraganore et al., 2006).

\section{LRRK2}

Two LRRK2 variants appear to be risk variants for PD in Asian populations, but it could not confirmed in other populations. The p.G2385R polymorphism is associated with the increased risk for PD in Taiwan, Chinese, Japanese and a Korean populations (Di Fonzo et al., 2006, Farrer et al., 2007, Funayama et al., 2007, Kim et al., 2010). The second LRRK2 risk allele is the p.R1628P variant. It seems to increase the risk of PD twofold in Chinese populations, but this variant was not associated with PD in Malays (Tan et al., 2008). In 2011, Ross and colleagues identified a new variant (p.M1646T) in Caucasian individuals, which showed a higher risk for PD (Ross et al., 2011).

\section{MAPT: microtubule-associated protein tau}

The MAPT gene mutations were initially identified as causative for frontotemporal dementia with parkinsonism linked to chromosome 17 (Hutton et al., 1998). To date, large number of mutations have been reported in this gene, causing parkinsonian symptoms (Ludolph et al., 2009), although pathogenic mutations have not been found in PD.

MAPT locus has two common haplotype groups, termed H1 and H2 (Stefansson et al., 2005). Associations between these haplotypes and risk for PD has been investigated in number of studies, and the results show an association between the H1 haplotype and PD (Pastor et al., 2000, Skipper et al., 2004, Zabetian et al., 2007). A join effects between genetic variants in SNCA and in the MAPT gene has been described; the combination of risk genotypes in SNCA and MAPT doubles the risk of PD (Goris et al., 2007).

\section{GBA: glucocerebrosidase}

Gaucher's disease (GD) is an autosomal recessively inherited glycolipid storage disorder caused by a deficiency of the lysosomal enzyme GBA. The most common clinical presentation is liver damage, however, there are other features of the disease, like neurological 
manifestations (Wong et al., 2004). GD is classified into three types: type 1, the most common form, has no associated neurological symptoms; type 2, or acute neuropathic disease, displays severe neurological involvement leading to death within the first years of life; type 3 , or chronic neuronopathic GD, exhibits varying degrees of systemic involvement with at least one neurological manifestation (Hruska et al., 2006, Dandana et al., 2016).

The GBA gene is localized at chromosome 1q21, and comprises 11 exon encoding a 497 amino acid protein. So far, more than 300 mutations of this gene have been identified, including point mutations, deletions, and recombination alleles derived from a nearby located pseudogene (Hruska et al., 2008) (Figure 1). Regarding the phenotype, many of these mutations have been classified as "null", "mild" or "severe", depending on the resulting level of GBA production. Null mutation (c.84dupG) do not lead to any enzyme production. Mild mutations, such as p.N370S, are associated with type 1 disease. Severe mutations, such as p.L444P, result in enzyme production and are associated with type 2 or 3 (Beutler et al., 2005).

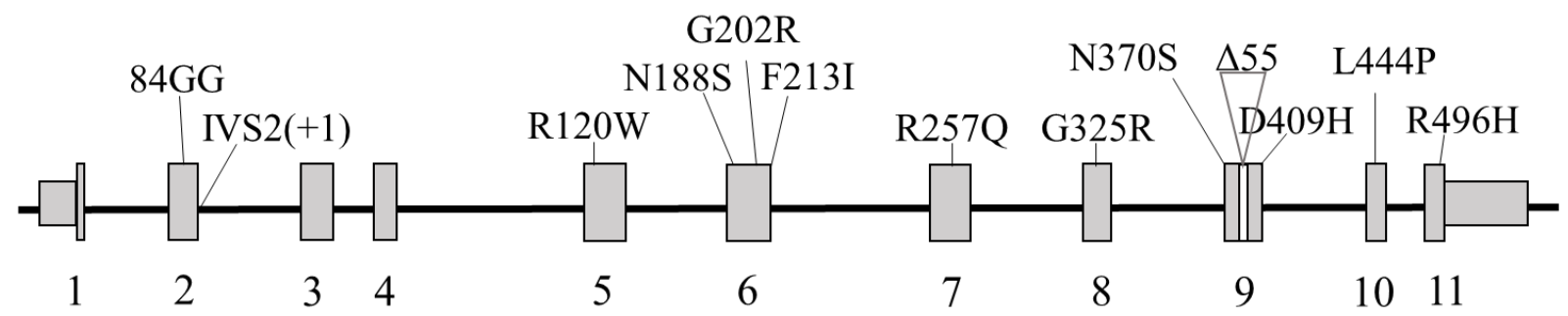

Figure 1. The exonic structure of GBA gene and positions of 13 common mutations.

The phenotype of GD and PD do not normally overlap, but the first indication for a relationship between the two disease come from clinical observation. Until recently, several studies have reported a clinical, neuropathological or genetic association between GD and PD (Clark et al., 2007, Lesage et al., 2011, Brockmann and Berg, 2014). First, Neudorfer et al. described that GD patients and their relatives frequently had parkinsonism (Neudorfer et al., 1996, GokerAlpan et al., 2004). This examination led to conclusion that the heterozygous mutations of GBA gene may be a risk factor for PD.

Numerous genotyping studies have demonstrated associations between several GBA mutations and PD in different ethnic groups. As an example, the frequencies of GBA mutations in PD patients were highest amongst Ashkenazi Jews (ranging from 13.7\% to 31.3\%) (Aharon-Peretz et al., 2004, Clark et al., 2005, Gan-Or et al., 2008). Furthermore, several studies have indicated that a high frequency of GBA mutations is related to an increased risk of PD amongst Japanese, 
Canadian, Portuguese, Greek, Norwegian, Italian, Serbian and Chinese populations (Sato et al., 2005a, Toft et al., 2006, De Marco et al., 2008, Bras et al., 2009, Mitsui et al., 2009, Moraitou et al., 2011, Wang et al., 2012, Zhang et al., 2012, Kumar et al., 2013). A recent meta-analyses have revealed that GBA variants are the most common genetic risk factors associated with PD, increasing the risk of PD $\sim 5$ fold, and the three most frequent mutations in non-Ashkenazi Jewish PD patients are p.N370S, p.L444P and p.R120W (Sidransky et al., 2009).

Although the precise mechanisms between GBA mutations and the development of PD is still unknown, some hypotheses have been reported to explain it, including loss-of-function and gain-of-function theories.

The loss-of-function theories focus on altered lipid metabolism. It has been detected that SNCA binds to lipids in the plasma membrane and synaptic vesicles (Jo et al., 2000). The binding of lipids may be protect the fibrillar forms of SNCA and inhibit the aggregation of this protein. It has been supposed that mutant GBA protein lead enzymatic deficiency which may alter the sphingolipid composition of membranes and disturbed membrane binding of SNCA, thereby increasing its accumulation in the cytoplasm ( $\mathrm{Li}$ et al., 2015).

The gain-of-function theories suppose that the missense mutations of GBA result in a misfolded protein. The GCase dysfunction might lead to lysosomal insufficiency, thereby reducing SNCA degradation (Li et al., 2015).

Both theories postulate reduced enzyme activity of GCase, therefore it was investigated in number of studies (Gegg and Schapira, 2018). GCase enzyme activity was significantly reduced in the SN (58\%), putamen (48\%), amygdala (40\%) and cerebellum (47\%) in PD-GBA patients (Gegg et al., 2012). Similar results were observed in fibroblasts from patients with GD and heterozygous mutation carriers with or without PD compared to control (McNeill et al., 2014). Moreover, GCase activity from fresh blood was measured in PD patients with and without GBA mutations, and GD patients. GBA mutation carriers PD patients had a lower GCase enzyme activity (median $16 \mathrm{nmol} / \mathrm{mg}$ protein/hour) compared to non-carriers (median $28.5 \mathrm{nmol} / \mathrm{mg}$ protein/hour) (Ortega et al., 2016). 


\section{Other PD-associated genes}

Besides the causative genes and risk factors, several polymorphisms in various genes were described which associated with PD, like BACE1, PITX3 and COX2 (Liu et al., 2011, Dai et al., 2015, Lange et al., 2015). Furthermore, several researches were focused on VDR gene and identified some polymorphic variants which may be associated with PD (Niu et al., 2015).

\section{VDR: vitamin D receptor}

Vitamin D, as an environmental factor, has been the subject of various studies on different neurological disorders, from which it has emerged that a vitamin D deficiency is associated with an increased risk of many diseases, including schizophrenia, autism, multiple sclerosis, Alzheimer's disease and PD (Sato et al., 1997, Sato et al., 1998, McGrath, 1999, Munger et al., 2006, Newmark and Newmark, 2007, Cannell, 2008, Evatt et al., 2008, Ascherio et al., 2010, Buell et al., 2010, Mowry, 2011, Orton et al., 2011, Amezcua et al., 2012).

In humans, the majority of vitamin D is synthesized via the cleavage of a cholesterol metabolite in the epidermis by UVB, with further metabolism to the primary circulating form of vitamin D, 25-hydroxyvitamin D (25OHD), in the liver. This compound circulates in the blood in a form bound to vitamin D binding protein and in the kidneys 25OHD is metabolized by 1- $\alpha$ hydroxylase to its active form, 1,25-dihydroxyvitamin D (1,25OHD). 1,25OHD binds to vitamin D receptors (VDRs) and influences calcium homeostasis, neurotrophic signalling, immunoregulation, cell growth and differentiation (Kato, 2000, Dusso et al., 2005, Kesby et al., 2011).

Besides these molecular mechanisms, epidemiological evidence have shown the potential value of vitamin D in PD prevention. The level of vitamin D in PD has been analysed in number of studies. A Japanese population exhibited a higher incidence of hip fractures and lower serum levels of 25OHD in PD patients as compared with the healthy controls (Sato et al., 1997, Sato et al., 2005b), observations that were confirmed in a Caucasian population (Evatt et al., 2008). The serum 25OHD level correlated negatively with the severity of PD, measured in terms of the Hoehn \& Yahr (HY) stage and the Unified Parkinson's Disease Rating Scale (UPDRS) (Sato et al., 1997, Sato et al., 2005b, Suzuki et al., 2012). Whereas Sato et al. (Sato et al., 2005b) reported a negative correlation between the 1,25OHD level and the UPDRS score, Suzuki et al. (Suzuki et al., 2012) could not confirm this finding. Later, a clinical trial in Japan directly demonstrated that vitamin D supplementation reduced the risk of PD development (Knekt et al., 2010) and prevented the deterioration of HY stage in PD patients (Suzuki et al., 2013) . 
The VDR gene encodes a nuclear transcription factor, and widely expressed in the nervous system. The highest expression level is found in the SN (Eyles et al., 2005).

The human gene is localized to $12 \mathrm{q} 12$ and various polymorphisms have been reported in it (Zmuda et al., 2000) (Figure 2).

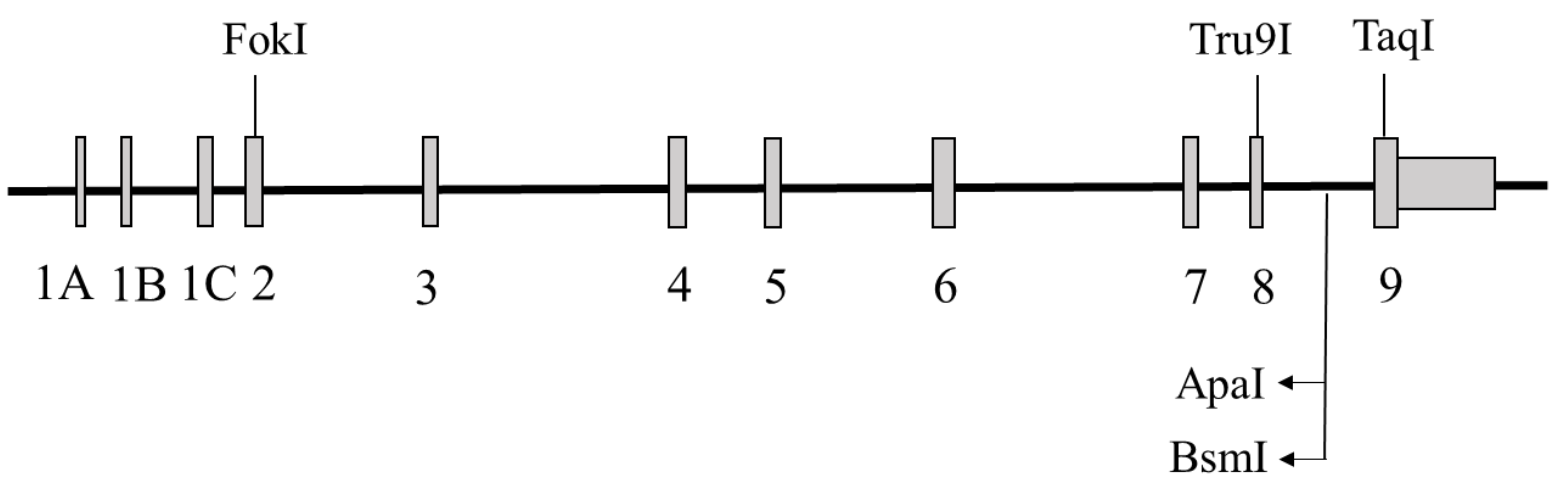

Figure 2. Schematic diagram of human VDR gene with the polymorphic sites.

Among the polymorphisms, BsmI, ApaI, TaqI and FokI are the most studied polymorphisms. However, only limited data are available regarding the association between VDR polymorphisms and PD, and the results have been contradictory. Suzuki et al. (Suzuki et al., 2012) found that FokI CC genotype was associated with milder forms of PD in a Japanese population. Furthermore, an association between the BsmI bb genotype and PD was demonstrated in a Korean population (Kim et al., 2005). A recent genome-wide association study revealed the association of VDR polymorphisms with the risk of PD and the age at onset in a Caucasian population (Butler et al., 2011). In a Chinese study it was described that FokI C allele associates with an increased risk of PD as well as early-onset PD (Han et al., 2012). 


\section{AIMS OF THE WORK}

Several causative genes have been identified, including VPS35, which are associated with PD. Besides causative genes, genetic risk factors and several polymorphisms in various genes have been reported which play a role in the development of PD, like mutations of GBA and VDR genes. The mutations were investigated in Caucasian population, mainly in Western and Northern Europe, but the results are controversial, and is well known, that the distribution of the mutations show geographical and ethnical variations. Moreover, there are only limited data from the Middle and Eastern Europe. Previously, the most frequent PD causing LRRK2 p.G2019S mutation was investigated in a Hungarian PD patient group, but there are no study has been conducted previously to assess the frequency of VPS35, GBA or VDR gene mutations in Hungarian PD patients.

The general aim of our work was to determine the frequency of some PD associated mutations in the Hungarian population, which belongs to the Caucasian race.

The specific aims of the work were:

- To investigate whether the p.D620N mutation of the VPS35 gene is present in SPD in the Hungarian population.

- To analyse the possible association between p.L444P, p.N370S and p.R120W mutations of the GBA gene in PD patients and controls. To investigate relationship between age at onset in the PD patients and GBA mutations.

- To examine the genotype distribution of VDR ApaI, FokI, TaqI or BsmI polymorphisms in Hungarian PD patients and controls. Moreover, we want to analyse the possible associations between the age at onset, the male-female ratio and the VDR polymorphisms in the PD group. 


\section{MATERIAL AND METHODS}

\subsection{Subjects}

\subsubsection{VPS35 and GBA mutations analysis}

124 SPD patients and 122 healthy control subjects were enrolled in the study. The demographic characteristics of the patient and control populations are summarized in Table 2. The study group were age-matched.

\begin{tabular}{lll}
\hline & PD group & Control group \\
\hline No. & 124 & 122 \\
Age (years, mean \pm SD) & $66.5 \pm 9.5$ & $64.3 \pm 8.2$ \\
Age at onset $\leq 60$ years & $67(54 \%)$ & N.A. \\
Age at onset $>60$ years & $57(46 \%)$ & N.A. \\
\hline
\end{tabular}

Table 2. Characteristics of groups of PD patients and controls

\subsubsection{Detection of VDR polymorphisms}

The demographic data of the patient and control groups are presented in Table 3. 100 SPD patients and 109 age-matched healthy controls were enrolled the analysis of VDR polymorphisms.

\begin{tabular}{lll}
\hline & PD group $(\%)$ & Control group (\%) \\
\hline No. & 100 & 109 \\
Age $($ mean \pm SEM) & $66.4 \pm 9.3$ & $64.0 \pm 8.2$ \\
Age at onset $\leq 60$ & $52(52)$ & N.A. \\
Age at onset $>60$ & $48(48)$ & N.A. \\
Gender & & \\
$\quad$ Male & $44(44)$ & $54(49.5)$ \\
$\quad$ Female & $56(56)$ & $55(50.5)$ \\
\hline
\end{tabular}

Table 3. Characteristics of PD patients and healthy controls in VDR polymorphism analysis

All of the patients were examined by movement disorder specialists, who confirmed the diagnosis of SPD. Patients with secondary parkinsonism were excluded. The PARK2 and PARK8 mutations were not present in the assessed patient population. Early-onset PD (EOPD) was defined as an age at onset $\leq 60$ years and late-onset PD (LOPD) as an age at onset $>60$ years. The control group individuals had no history of neurological or psychiatric disorders. All the patients with SPD and all the controls were of Hungarian origin and were selected from the Department of Neurology at the University of Szeged. 
The study protocol was approved by the Medical Research Council Scientific and Research Ethics Committee (47066-3/2013/EKU (556/2013)) and Ethics Committee of the Faculty of Medicine (22/2012), University of Szeged. All study participants gave their written informed consent in accordance with the Helsinki Declaration.

\subsection{DNA isolation}

From all participants peripheral blood was taken from a cubital vein in a tube with EDTA and stored $4^{\circ} \mathrm{C}$. Genomic DNA was extracted by a standard desalting method (Miller et al., 1988), and stored at $-20^{\circ} \mathrm{C}$ until further use.

All polymorphisms were determined by polymerase chain reaction (PCR) techniques in a thermal cycler (Applied Biosystems 2720 Thermal Cycler, Applied Biosystems, Foster City, CA, USA) and restriction fragment-length polymorphism (RFLP).

\subsection{Detection of VPS35 mutation}

The p.D620N mutation of VPS35 gene were amplified with previously described PCR conditions and primers (Sudhaman et al., 2013): forward primer 5'- AGG CTG CAG AAG TCT CAC AGG A-3'and reverse primer 5'- AGG GCA GGG GGA CAG TGA AGA-3'. The PCR conditions were: $95^{\circ} \mathrm{C}$ for $2 \mathrm{~min}, 95{ }^{\circ} \mathrm{C}$ for $30 \mathrm{~s}, 58{ }^{\circ} \mathrm{C}$ for $30 \mathrm{~s}$ and $72{ }^{\circ} \mathrm{C}$ for $45 \mathrm{~s}$ for 35 cycles, and finally $72{ }^{\circ} \mathrm{C}$ for $7 \mathrm{~min}$. The PCR products were digested with the HinFI restriction enzyme (Thermo Scientific, Waltham, MA, USA) at $37{ }^{\circ} \mathrm{C}$ for $30 \mathrm{~min}$. The digested products were separated by agarose gel electrophoresis. The genotypes were defined as GG (257 bp, 231 bp, 139 bp, 74 bp, and 18 bp), GA (257 bp, 231 bp, 213 bp, 139 bp, 74 bp, and 18 bp) or AA (257 bp, 231 bp, 213 bp, and 18 bp).

\subsection{Analysis of GBA mutations}

Three previously described primer pairs were used separately to amplify the DNA region of each mutation (Aharon-Peretz et al., 2004, Wu et al., 2007).

PCR amplification of the polymorphic p.L444P site (rs421016) was performed with the following primers: forward 5'-GGA GGA CCC AAT TGG GTG CGT-3' and reverse 5'-ACG CTG TCT TCA GCC CAC TTC-3'. The PCR conditions were as follows: $95{ }^{\circ} \mathrm{C}$ for $10 \mathrm{~min}$, $95{ }^{\circ} \mathrm{C}$ for $30 \mathrm{~s}, 59^{\circ} \mathrm{C}$ for $30 \mathrm{~s}$ and $72{ }^{\circ} \mathrm{C}$ for $1 \mathrm{~min}$ for 35 cycles, and finally $72{ }^{\circ} \mathrm{C}$ for $5 \mathrm{~min}$. After the PCR reaction, the products were digested with the restriction enzyme NciI (Fermentas, 
Vilnius, Lithuania) at $37{ }^{\circ} \mathrm{C}$ overnight. Fragments were separated by electrophoresis in $2 \%$ stained agarose gels and visualized in UV light. The genotypes were defined as AA (637 bp), GG (535 and 102 bp) or AG (637, 535 and 102 bp).

Previously published primers were used to detect the p.R120W (rs397515515) mutation: forward 5'-GCA GAG TCC CAT ACT CTC CT-3' and reverse 5'-TGG GTG ACA GAG AGA GAG ACT-3'. The PCR conditions differed only the annealing temperature from the p.L444P mutation used conditions. Here the annealing temperature was $56^{\circ} \mathrm{C}$. The PCR products were digested with NciI restriction enzyme at $37{ }^{\circ} \mathrm{C}$ overnight to identify the genotypes. The digested fragments were visualized in $2 \%$ stained agarose gel: CC (454, 300 and 82 bp), CT (536, 454, 300 and $82 \mathrm{bp}$ ) and TT (536 and $300 \mathrm{bp}$ ).

The p.N370S (rs76763715) polymorphisms of the GBA gene were determined by using the following primers and PCR conditions: forward 5'-GCC TTT GTC CTT ACC CTC $\uparrow \mathrm{G}-3$ ', reverse 5'-GAC AAA GTT ACG CAC CCA A-3'; $95^{\circ} \mathrm{C}$ for $10 \mathrm{~min}, 95^{\circ} \mathrm{C}$ for $30 \mathrm{~s}, 53{ }^{\circ} \mathrm{C}$ for $30 \mathrm{~s}$ and $72{ }^{\circ} \mathrm{C}$ for $30 \mathrm{~s}$ for 35 cycles, and finally $72{ }^{\circ} \mathrm{C}$ for $5 \mathrm{~min}$. $\dagger$ A mismatch was introduced in the primer at one nucleotide to create a restriction site.

Following amplification, the products were digested with $\mathrm{XhoI}$ at $37^{\circ} \mathrm{C}$ overnight and electrophoresed on $4 \%$ agarose gels. The absence of restriction site on both alleles result in 105 bp fragments (AA). The presence of the restriction site on both alleles (CC) led to 89 and 16 bp. In case of heterozygotes (CT), the presence of all three bands (105, 89 and 16 bp) needed.

\subsection{Genotyping of VDR polymorphisms}

For amplification of the FokI C/T polymorphism (rs10735810) the following primers were used (Harris et al., 1997): forward primer 5'-AGC TGG CCC TGG CAC TGA CTC TGC TCT-3' and reverse primer 5'-ATG GAA ACA CCT TGC TTC TTC TCC CTC-3'. The PCR amplification was carried out with the following cycling parameters: $95{ }^{\circ} \mathrm{C}$ for $5 \mathrm{~min}$, and then 30 cycles of $95{ }^{\circ} \mathrm{C}$ for $30 \mathrm{~s}, 60{ }^{\circ} \mathrm{C}$ for $30 \mathrm{~s}$, and $72{ }^{\circ} \mathrm{C}$ for $30 \mathrm{~s}$, and finally $72{ }^{\circ} \mathrm{C}$ for $7 \mathrm{~min}$. The PCR products were digested with the FokI restriction enzyme (Fermentas, Vilnius, Lithuania) at $55{ }^{\circ} \mathrm{C}$ for $3 \mathrm{~h}$. The digested products were separated by agarose gel electrophoresis. The genotypes were defined as CC (265 bp), TT (169 and 96 bp) or CT (265, 169 and 96 bp).

The BsmI A/G polymorphic site of intron 8 (rs1544410) was amplified with previously described primers (Kim et al., 2005): forward primer 5'-CAA CCA AGA CTA CAA GTA CCG CGT CAG TGA-3' and reverse primer 5'-AAC CAG CGG GAA GAG GTC AAG GG-3'. The PCR conditions were as follows: $95{ }^{\circ} \mathrm{C}$ for $10 \mathrm{~min}, 95^{\circ} \mathrm{C}$ for $30 \mathrm{~s}, 59^{\circ} \mathrm{C}$ for $30 \mathrm{~s}$ and $72{ }^{\circ} \mathrm{C}$ for 
$50 \mathrm{~s}$ for 35 cycles, and finally $72{ }^{\circ} \mathrm{C}$ for $10 \mathrm{~min}$. The PCR products were digested with the restriction enzyme Mva12691 (Fermentas, Vilnius, Lithuania) at $37{ }^{\circ} \mathrm{C}$ overnight. Fragments were separated by electrophoresis in $2 \%$ stained agarose gels and visualized in UV light. The genotypes were defined as AA (825 bp), GG (650 and $175 \mathrm{bp}$ ) or AG (825, 650 and $175 \mathrm{bp}$ ). PCR amplification of the polymorphic TaqI T/C site (rs731236) was performed with the following primers (Riggs et al., 1995): forward 5'-CAG AGC ATG GAC AGG GAG CAA-3' and reverse 5'-CAC TTC GAG CAC AAG GGG CGT TAG C-3'. The PCR conditions were identical to those for the BsmI polymorphism. The PCR products were digested with the TaqI restriction enzyme (Fermentas, Vilnius, Lithuania) at $65^{\circ} \mathrm{C}$ for $3 \mathrm{~h}$ and fragments were analysed by electrophoresis in $2 \%$ agarose gel. The absence of the TaqI restriction site on both alleles (TT) led to the $501 \mathrm{bp}$ fragment, whereas the presence of the restriction site on both alleles (CC) yielded bands of 295 and $206 \mathrm{bp}$. The presence of the 501, 295 and $206 \mathrm{bp}$ fragments reflected the TC heterozygotes.

The ApaI G/T polymorphic site (rs7976091) was amplified with previously described primers (Sainz et al., 1997): forward primer 5'-CAA CCA AGA CTA CAA GTA CCG CGT CAG TGA-3' and reverse primer 5'-CAC TTC GAG CAC AAG GGG CGT TAG C-3' The PCR conditions were: $95^{\circ} \mathrm{C}$ for $10 \mathrm{~min}$, followed by 35 cycles of $95^{\circ} \mathrm{C}$ for $30 \mathrm{~s}, 59^{\circ} \mathrm{C}$ for $30 \mathrm{~s}$ and $72{ }^{\circ} \mathrm{C}$ for $2 \mathrm{~min}$, and finally $72{ }^{\circ} \mathrm{C}$ for $7 \mathrm{~min}$. The PCR products were incubated with the ApaI restriction enzyme (Fermentas, Vilnius, Lithuania) at $37{ }^{\circ} \mathrm{C}$ overnight. The genotypes were defined as TT (absence of restriction site, one band at 2000 bp), TG (heterozygote, three bands at 2000, 1700 and $300 \mathrm{bp}$ ) and GG (presence of the restriction site, two bands at 1700 and 300 bp).

\subsection{Statistical analysis}

SPSS software version 22.0 was applied for the evaluation of the data populations (SPSS Inc., Chicago, IL, USA). The genotype frequencies in the patients and the controls were analysed by using the Fisher exact test or the $\chi^{2}$ test. The normality of the data was checked with the Kolmogorov-Smirnov test. Since the data exhibited Gaussian distribution, and the Levene test did not reveal significant differences in the homogeneity of variances, we applied the independent $t$ test for the comparison of the difference in age between the PD groups and the controls. The associations between the genotypes and the PD were estimated via the odds ratio (OR), with a $95 \%$ confidence interval (CI) $(95 \% \mathrm{CI})$. A p value of less than 0.05 was considered statistically significant. The observed FokI, BsmI, ApaI and TaqI genotype frequencies were in accordance with the Hardy-Weinberg equilibrium in both the patients and the controls. 


\section{RESULTS}

\subsection{VPS35 gene mutation}

The common VPS35 p.D620N mutation was not detected either in the PD patients or in the controls in the assessed population (Table 4).

\begin{tabular}{llll}
\hline & \multicolumn{3}{c}{ Genotype } \\
\hline & GG $(\%)$ & GA $(\%)$ & AA $(\%)$ \\
\hline PD patients & $124(100)$ & $0(0)$ & $0(0)$ \\
Control & $122(100)$ & $0(0)$ & $0(0)$ \\
\hline
\end{tabular}

Table 4. Distribution of p.D620N mutation in the PD patients and the control group

\subsection{GBA gene mutations}

Among PD patients, 3 individuals (2.4\%) carried a heterozygous mutant GBA allele: in all 3 cases the p.L444P substitution. In contrast, no mutations were detected in the control group. The difference in mutation frequencies between the patients $(2.4 \%)$ and controls $(0 \%)$ was not statistically significant ( $\mathrm{p}=0.247$ ) (Table 5). However, the carriers of the GBA mutation were at an increased risk of developing $\mathrm{PD}(\mathrm{OR}=6.05,95 \%$ CI 0.300 to 122.06$)$.

\begin{tabular}{lllll}
\hline \multicolumn{5}{c}{ Genotype } \\
\hline & AA (\%) & AG (\%) & GG (\%) & p \\
\hline PD patients & $121(97.6)$ & $3(2.4)$ & $0(0)$ & 0.247 \\
Control & $122(100)$ & $0(0)$ & $0(0)$ & \\
\hline
\end{tabular}

Table 5. GBA p.L444P genotypes distributions in patients with PD and controls

Moreover, all the patients who carried the mutant allele were in the EOPD group. The frequency was significantly higher in the EOPD group than in the controls $(p=0.042)$. However, a comparison of the frequency between the EOPD group and the LOPD group failed to reveal any difference $(\mathrm{p}=0.247)$ (Table 6$)$.

\begin{tabular}{cllll}
\hline & AA (\%) & AG (\%) & GG (\%) & p \\
\hline $\begin{array}{c}\text { Age at onset } \\
\leq 60 \mathrm{yr}\end{array}$ & $64(95.5)$ & $3(4.5)$ & $0(0)$ & 0.247 \\
$>60 \mathrm{yr}$ & $57(100)$ & $0(0)$ & $0(0)$ & \\
\hline
\end{tabular}

Table 6. Relationship between age at onset in the PD patients as a function of the GBA p.L444P genotyping 
Neither the p.R120W nor the p.N370S variant of the GBA gene was identified among the assessed PD cases and controls (Table 7.).

\begin{tabular}{lllllll}
\hline \multicolumn{3}{c}{ R120W } & \multicolumn{3}{l}{ N370S } \\
\hline & CC (\%) & CT $(\%)$ & TT $(\%)$ & TT $(\%)$ & TC $(\%)$ & CC $(\%)$ \\
\hline PD patients & $124(100)$ & $0(0)$ & $0(0)$ & $124(100)$ & $0(0)$ & $0(0)$ \\
Control & $122(100)$ & $0(0)$ & $0(0)$ & $122(100)$ & $0(0)$ & $0(0)$ \\
\hline
\end{tabular}

Table 7. Distribution of R120W and N370S mutations of GBA gene in patients with PD and controls

\subsection{VDR polymorphisms}

\section{VDR FokI polymorphism}

The distributions of FokI restriction site genotypes in the PD patients and the controls are shown in Table 8. There was a significant difference in genotypes between the PD patients and the healthy controls $\left(\chi^{2}=6.7 ; p=0.035\right)$. The frequency of genotype with $\mathrm{C}(\mathrm{CC}+\mathrm{CT})$ was significantly higher among the patients with PD relative to the controls: $\mathrm{OR}=2.677$ and $95 \%$ $\mathrm{CI}=1.214-5.91, \mathrm{p}=0.015$ for $\mathrm{CC}+\mathrm{CT}$ vs. TT. Moreover, the $\mathrm{C}$ allele showed a significant association with PD group $(\mathrm{OR}=1.615,95 \% \mathrm{CI}=1.087-2.399, \mathrm{p}=0.017)$. There was no difference between the FokI polymorphism and gender in PD group, and no significant association was found between this polymorphism and the age at onset (Table 9).

\begin{tabular}{llllllll}
\hline & \multicolumn{3}{c}{ Genotype } & \multicolumn{3}{c}{ Allele frequency } \\
\hline & $\mathrm{CC}(\%)$ & $\mathrm{CT}(\%)$ & $\mathrm{TT}(\%)$ & $\mathrm{p}$ & $\mathrm{C}(\%)$ & $\mathrm{T}(\%)$ & $\mathrm{p}$ \\
\hline PD patients & $42(42)$ & $48(48)$ & $10(10)$ & \multirow{2}{*}{0.035} & $132(66)$ & $68(34)$ & \multirow{2}{*}{0.017} \\
Control & $35(32.1)$ & $49(45)$ & $25(22.9)$ & & $119(54.6)$ & $99(45.4)$ & \\
\hline
\end{tabular}

Table 8. VDR FokI genotypes and allele frequencies in the PD patients and the controls

\begin{tabular}{cllll}
\hline & $\mathrm{CC}(\%)$ & $\mathrm{CT}(\%)$ & $\mathrm{TT}(\%)$ & $\mathrm{p}$ \\
\hline $\begin{array}{c}\text { Age at onset } \\
\leq 60 \mathrm{yr}\end{array}$ & $22(42.3)$ & $24(46.2)$ & $6(11.5)$ & \\
$\quad>60 \mathrm{yr}$ & $20(41.7)$ & $24(50)$ & $4(8.3)$ & 0.841 \\
$\begin{array}{c}\text { Gender } \\
\text { Male }\end{array}$ & $18(40.9)$ & $22(50)$ & $4(9.1)$ & \\
Female & $24(42.9)$ & $26(46.4)$ & $6(10.7)$ & 0.958 \\
\hline
\end{tabular}

Table 9. Relationship between age at onset and gender in the PD patients as a function of the VDR FokI genotyping 


\section{VDR BsmI polymorphism}

There was no significant difference in the $\mathrm{BsmI}$ genotypic distribution $(\mathrm{OR}=0.890,95 \% \mathrm{CI}=$ $0.478-1.654, \mathrm{p}=0.753$ for $\mathrm{GG}$ vs. $\mathrm{AA}+\mathrm{AG})$ and allele frequency $(\mathrm{OR}=0.977,95 \% \mathrm{CI}=0.665$ 1.434, $\mathrm{p}=0.905$ ) between the PD patients and the healthy controls. The BsmI genotypic distribution, the allele frequency, the male to female ratio and the age at onset of the PD patients are presented in Table 10.

\begin{tabular}{llllllll}
\hline \multicolumn{3}{c}{ Genotype } & \multicolumn{5}{c}{ Allele frequency } \\
\hline & AA (\%) & AG (\%) & GG (\%) & p & A (\%) & G (\%) & p \\
\hline PD patients & $24(24)$ & $49(49)$ & $27(27)$ & 0.902 & $97(48.5)$ & $103(51.5)$ & 0.905 \\
Controls & $25(22.9)$ & $57(52.3)$ & $27(24.8)$ & & $107(49)$ & $111(51)$ & \\
$\begin{array}{c}\text { Age at onset } \\
\leq 60 \mathrm{yr}\end{array}$ & $9(17.3)$ & $27(51.9)$ & $16(30.8)$ & & & & \\
$\quad>60 \mathrm{yr}$ & $15(31.3)$ & $22(45.8)$ & $11(22.9)$ & & & & \\
$\begin{array}{c}\text { Gender } \\
\quad \text { Male }\end{array}$ & $7(15.9)$ & $22(50)$ & $15(34.1)$ & 0.161 & & & \\
$\quad$ Female & $17(30.4)$ & $27(48.2)$ & $12(21.4)$ & & & & \\
\hline
\end{tabular}

Table 10. VDR BsmI genotypes and allele distributions in patients with PD and controls

\section{VDR TaqI polymorphism}

The frequencies of the TaqI genotype in the PD group and the controls were similar (OR = $0.840,95 \% \mathrm{CI}=0.399-1.767, \mathrm{p}=0.646$ for $\mathrm{TT}+\mathrm{TC}$ vs. $\mathrm{CC}$ ) and we did not find differences in allele distribution $(\mathrm{OR}=0.802,95 \% \mathrm{CI}=0.540-1.190, \mathrm{p}=0.273)$. There was no significant difference in the male to female ratio and the age at onset in the various TaqI polymorphism subgroups (Table 11).

\begin{tabular}{|c|c|c|c|c|c|c|c|}
\hline & \multicolumn{3}{|c|}{ Genotype } & \multirow[b]{2}{*}{$\mathrm{p}$} & \multicolumn{3}{|c|}{ Allele frequency } \\
\hline & $\mathrm{TT}(\%)$ & $\mathrm{TC}(\%)$ & $\mathrm{CC}(\%)$ & & $\mathrm{T}(\%)$ & $\mathrm{C}(\%)$ & $\mathrm{p}$ \\
\hline PD patients & $35(35)$ & $48(48)$ & $17(17)$ & \multirow{2}{*}{0.485} & $118(59)$ & $82(41)$ & \multirow{2}{*}{0.273} \\
\hline Controls & $47(43.1)$ & $46(42.2)$ & $16(14.7)$ & & $140(64.2)$ & $78(35.8)$ & \\
\hline Age at onset & & & & & & & \\
\hline$\leq 60 \mathrm{yr}$ & $22(42.3)$ & $23(44.2)$ & $7(13.5)$ & \multirow{2}{*}{0.265} & & & \\
\hline$>60 \mathrm{yr}$ & $13(27.1)$ & $25(52.1)$ & $10(20.8)$ & & & & \\
\hline \multicolumn{8}{|l|}{ Gender } \\
\hline Male & $18(40.9)$ & $20(45.5)$ & $6(13.6)$ & \multirow{2}{*}{0.528} & & & \\
\hline Female & $17(30.4)$ & $28(50)$ & $11(19.6)$ & & & & \\
\hline
\end{tabular}

Table 11. VDR TaqI genotypes and allele frequencies in patients with PD and controls 


\section{VDR ApaI polymorphism}

The ApaI genotype frequencies $(\mathrm{OR}=1.352,95 \% \mathrm{CI}=0.654-2.796, \mathrm{p}=0.466$ for $\mathrm{GG}$ vs. $\mathrm{TT}+\mathrm{TG})$ and the allele distribution $(\mathrm{OR}=1.177,95 \% \mathrm{CI}=0.793-1.748, \mathrm{p}=0.417)$ were similar in the healthy controls and the patients with PD. There was no statistically significant association between the ApaI polymorphism and the age at onset in PD patients, and no significant difference was found between this polymorphism and gender in the PD group (Table 12).

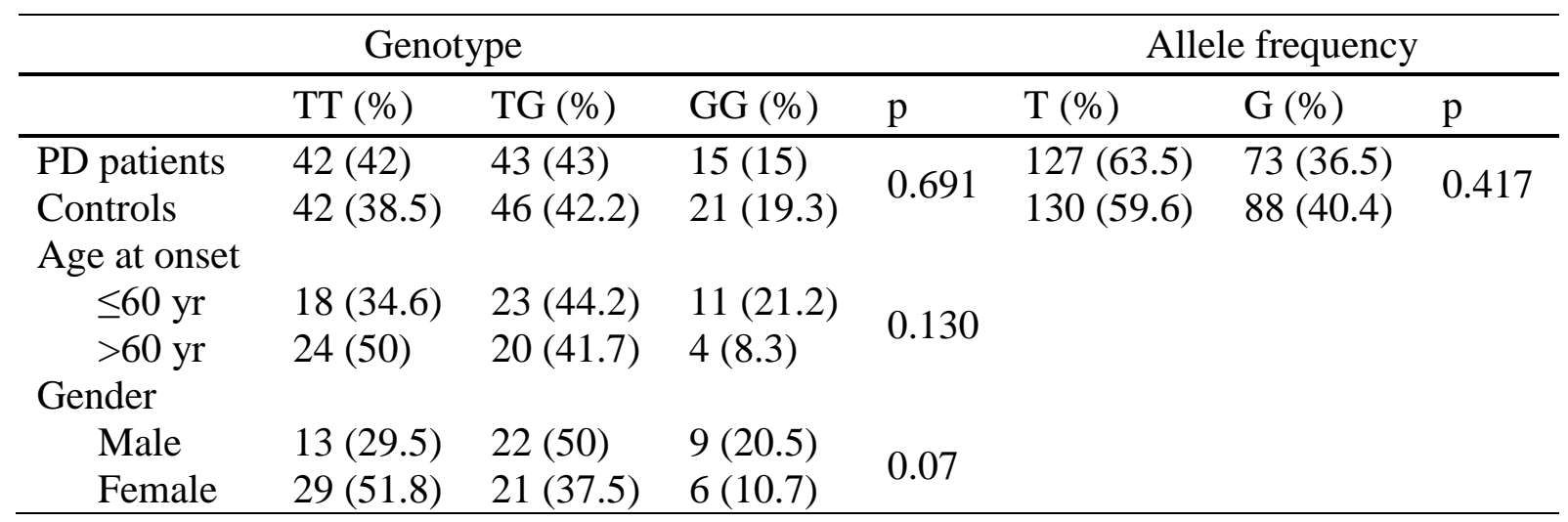

Table 12. VDR ApaI genotypes and allele frequencies in the PD patients and the controls 


\section{DISCUSSION}

PD is a frequent and heterogeneous disorder. The majority of PD cases (80-85\%) are sporadic; the remaining $15-20 \%$ of the patients have a familial history. The precise patomechanism of PD is not fully understood, therefore the treatment poses a great challenge for clinical investigation. For this reason, it would be important to determine genetic alterations may promote the selection of homogenous subpopulations, hereby a target specific therapy would be enable in the different subgroups. It is well known, that the environmental factors influence the development of PD, but the sensibility to environmental factors is mostly determined by genetic and epigenetic background.

Molecular genetics has identified several genes which linked to monogenic forms of PD with autosomal dominant or autosomal recessive inheritance.

Although the monogenic forms less than $10 \%$ of Mendelian cases, these genes also play an important role in the pathogenesis of sporadic forms of PD (Dawson and Dawson, 2010, Lubbe and Morris, 2014). To date, the frequent PD causing LRRK2 p.G2019S mutation was examined in Hungarian PD patients, but this mutation has not been detected in anyone (Balicza et al., 2012).

\section{p.D620N mutation of VPS35 gene in PD}

VPS35 is a subunit of retromer complex and is involved in endosomal-lysosomal trafficking.

Recent studies focused on the link between the retromer complex and PD and have been investigated in different model organisms. Decreased VPS35 levels in Drosophila dopaminergic neurons were shown to lead to locomotor defects and shortened lifespan (Linhart et al., 2014). In addition, the expression of the VPS35 with p.D620N mutation in the rat brain was shown to cause a dopaminergic neuron degeneration (Tsika et al., 2014). Furthermore, the p.D620N mutation in VPS35 (PARK17) was recently discovered as a new cause of PD, mainly in the autosomal dominantly inherited cases, although it may additionally have a role in SPD, but the results are inconsistent (Vilarino-Guell et al., 2011, Zimprich et al., 2011). The frequency of the mutation carriers have been estimated ranging from $0.1 \%$ to $1 \%$ of the PD population (Kumar et al., 2012). The distribution of the VPS35 mutation shows ethnic differences; the p.D620N mutation is more frequent in Yemenite Jews (1.67\%), in France $(1.2 \%)$, in Tunisia $(0.5 \%)$, and in Austria (0.4\%), however this mutation has not been found in other ethnicities, like in Canada, Norway, Ireland, Taiwan, Chinese and Greeks (Deng et al., 
2013, Kalinderi et al., 2015). Noticeably, this mutation has been examined in a number of Caucasian populations with different results. Therefore, we investigated the presence of the p.D620N mutation of the VPS35 gene in Hungarian SPD patients, but we were unable to identify this mutation in any of the investigated patients or controls indicating that the frequency is less than $0.8 \%$. This data is similar to those of previous studies that have reported associations between this mutations and PD in other Caucasian populations. This suggests that the p.D620N mutation of the VPS35 gene is a rare cause of SPD.

\section{Association between GBA mutations and PD}

Besides the Mendelian genes, several studies have focused on genetic variability conferring susceptibility to sporadic PD. GWAS studies are carried out to identify rare genetic variants that increase the risk of PD. Multiple GWAS in PD patients and controls have revealed numerous loci, including GBA and MAPT, as risk factors for sporadic PD (Vacic et al., 2014). GBA gene encode a lysosomal enzyme and several mutation have been reported in it. The precise mechanisms underlying the relation between the mutations of GBA and the development of PD is still indefinable. Recent studies provide some perspectives; the link among GBA mutations, GCase activity, and SNCA has made an important contribution in the pathogenesis of PD (Li et al., 2015).

Several studies have reported that the frequencies of GBA mutations are higher in PD patients (5-10\%) than in controls, but the range varies in different ethnic groups (Schapira, 2015). p.L444P is the most common variant among non-Ashkenazi Jewish patients. Our results indicated that the PD patients demonstrated a higher frequency $(2.4 \%)$ of the p.L444P mutation of the GBA gene as compared with the controls $(0 \%)$, although the difference was not statistically significant. This finding is similar to those of previous studies that have reported associations between the p.L444P mutation and PD (Wu et al., 2007, Mao et al., 2010, Wang et al., 2012). The p.L444P mutation was shown to occur at incidences of $2 \%, 1.39 \%$ and $1.14 \%$ among American non-Jewish, Canadian and British PD patients, respectively (Sato et al., 2005a, Clark et al., 2007, Neumann et al., 2009). Moreover, an Eastern Canadian study concluded that the frequency of p.L444P was higher among PD patients (3.1\%) as compared with controls (Han et al., 2016).

A number of studies have found that GBA mutations may be considered a risk factor, mainly in EOPD cases (Clark et al., 2007, Wu et al., 2007, Gonzalez-Del Rincon Mde et al., 2013). Our study revealed that all the patients who carried the mutant allele were in the EOPD group. In accordance with our data higher p.L444P frequency was observed in some other European 
EOPD population, like Greece (3.3\%), Spain (2.66\%), and United Kingdom (1.15\%) (Kalinderi et al., 2009, Neumann et al., 2009, Seto-Salvia et al., 2012). These data emphasized the significance of the GBA mutation, particularly in EOPD cases.

Besides the p.L444P mutation, the other two most frequent genetic alterations in non-Ashkenazi Jewish patients are p.N370S and p.R120W (Sidransky et al., 2009), and we therefore investigated these two GBA mutations too. p.N370S has been demonstrated to be the most common mutation among Ashkenazi Jewish PD patients (14.1\%), and it is also the most frequent mutation in several European (e.g. Serbian (1.9\%), French (2.9\%) and Portuguese (2.2\%)) populations (Bras et al., 2009, Sidransky et al., 2009, Lesage et al., 2011, Kumar et al., 2013). A significant association between the p.R120W mutation and PD have been detected in a Japanese study (Mitsui et al., 2009). In contrast, we did not detect either the p.R120W or the p.N370S variant of the GBA gene among the PD cases and the controls, although the p.N370S mutation was earlier demonstrated in some European PD patients (Sidransky et al., 2009, Moraitou et al., 2011, Kumar et al., 2013). Our findings suggest that the frequency of these mutations are less than $0.8 \%$ in the investigated PD populations, more precise frequency could be determined by increasing of the sample size.

These diverse data suggest that the Caucasian population is not homogeneous in this respect.

\section{Association between VDR mutations and PD}

Earlier reports revealed that 25OHD levels were decreased in PD patients in Japanese and Caucasian populations (Sato et al., 1997, Sato et al., 2005b, Evatt et al., 2008) and demonstrated a higher incidence of osteoporosis in PD patients of both genders, with a decreased bone mass index and a reduced bone mineral density (Fink et al., 2005, Sato et al., 2005b). Overall, it has been clearly shown that the vitamin D metabolism is affected in PD patients. Additionally, differences have also been demonstrated in the VDR polymorphisms in PD in Japanese, Korean, Chinese and Caucasian populations (Kim et al., 2005, Butler et al., 2011, Han et al., 2012, Suzuki et al., 2012).

Our results have indicated a significant difference in the FokI genotype distribution between $\mathrm{PD}$ and controls in Hungarian population; the frequency of the $\mathrm{C}$ allele was significantly higher in PD patients than in the healthy control group, suggesting that the $\mathrm{C}$ allele may have a role in the development of PD. Previously, a Japanese and a Chinese study detected difference in this polymorphism between healthy subjects and PD patients. In Japan, FokI CC genotype was 
associated with mild PD (Suzuki et al., 2012). Han et al. (Han et al., 2012) suggested that FokI $\mathrm{C}$ allele might be a risk factor for sporadic PD development.

FokI polymorphism is located in exon 2 at the 5 ' coding region of the gene. This polymorphism results in different translation initiation sites: if the VDR gene contains $\mathrm{C}$ allele, the protein will be three amino acids shorter. Difference in length may result in altered VDR function (Arai et al., 1997, Zmuda et al., 2000).

BsmI, ApaI and TaqI polymorphisms are located in the 3'-end region of the VDR gene, which do not result in changes in the amino acid sequence of the VDR (Zmuda et al., 2000). We did not identify significant associations with these VDR polymorphisms. A Korean study detected difference in the genotype frequency of BsmI polymorphism between healthy subjects and PD patients; the bb genotype in that study was more common in Korean PD patients than in controls (Kim et al., 2005). No difference in BsmI polymorphism was identified in Japanese patients (Suzuki et al., 2012), where the FokI CC genotype displayed a strong association with the mild PD.

Our data demonstrated that there are no significant associations between VDR ApaI polymorphism and PD, whereas the ApaI polymorphism was associated with the EOPD in American Caucasians. Interestingly, there was no association between FokI polymorphism and PD patients among American Caucasians, reflecting differences in ethnicity among Caucasians (Butler et al., 2011). We did not detect an association between the age at onset, the male-female ratio and the VDR polymorphisms in the PD group. These diverse data suggest that the Caucasian population is not homogeneous in this respect.

As far as we are aware, this is the first report on the potential correlation between a VDR polymorphism and PD from a European country.

Since our data, a Taiwanese and a Faore Island study described no relationship between VDR polymorphisms and the risk of PD (Lin et al., 2014, Petersen et al., 2014). Furthermore, two recent meta-analysis indicated that the VDR BsmI, ApaI and TaqI polymorphisms are not associated with PD (Zhang et al., 2014, Niu et al., 2015) while the FokI polymorphism possibly associated with increased risk of PD (Niu et al., 2015). These data confirm our findings that the VDR FokI polymorphism increase the risk of PD.

The differences between the results of the various studies might stem from the different sample size and the different study populations with the possibility of certain ethnic variations.

The results suggest that the genetic analysis of SPD patients is important, because it could help to understand the development of PD and the design of future therapeutic studies. 


\section{CONCLUSION}

We investigated some mutations and polymorphisms which may associated with PD in Hungarian population. In this work, we have provided evidence at the first time that p.D620N mutation of VPS35 gene is not involved in the pathogenesis of the investigated Hungarian SPD patients. In contrast, p.L444P mutation of GBA gene showed a significant association with EOPD. Furthermore, a significant correlation were detected between FokI polymorphism of VDR gene and the investigated PD population.

As far as we aware, this is the first work on the potential association between a GBA mutation, VDR polymorphism and PD from Hungarian population.

The detection of the different genetic factors in the various PD group is important, because it may permit the development of new therapeutic targets. Furthermore, the identification of novel genetic risk factors may facilitate a better selection of homogeneous subpopulations for therapeutic studies.

Our study has limitations; the sample size is relatively small, therefore the detection of the rare genetic mutations are difficult. In the future we plan to increase the number of subject in the examination to be able to detect this rare mutations in PD patients even more representatively.

\section{ACKNOWLEDGEMENT}

These investigations were carried out within the Department of Neurology, Faculty of Medicine, University of Szeged.

I would like to thank my supervisor, Péter Klivényi MD, DSc, for the continuous help throughout the years we working together. He has taught me much about neuroscience and the scientific way of thinking. He provided me with advice and encouraged me to work hard.

I would also like to extend my thanks to László Vécsei MD, DSc, Head of the Department of Neurology, for the opportunity to work in the laboratory and his instructive suggestions throughout the projects. 
I am grateful to all my colleagues, especially Dr. Bernadett Tuka, Dr. Eszter Tóth, Dr. Nikoletta Szabó, Dr. Levente Szalárdy, Dr. Gábor Veres, Dr. Dénes Zádori and Andrea Tóth for their help and caring support during my work.

Last but not least, I would like to thank my family and my husband for their endless love, support and encouragement during my studies and in my private life.

This work was supported by the MTA-SZTE Neuroscience Research Group, the European Union and co-financed by the European Social Fund in the framework of TÁMOP 4.2.4.A/211-1-2012-0001 'National Excellence Program' and by the following grants: TÁMOP-4.2.1/B09/1/KONV-2010-0005, TÁMOP-4.2.2.A-11/1/KONV-2012-0052 and Hungarian Brain Research Program Grant no. KTIA_13_NAP-A-II/17. 


\section{REFERENCES}

Abbas N, Lucking CB, Ricard S, Durr A, Bonifati V, De Michele G, Bouley S, Vaughan JR, Gasser T, Marconi R, Broussolle E, Brefel-Courbon C, Harhangi BS, Oostra BA, Fabrizio E, Bohme GA, Pradier L, Wood NW, Filla A, Meco G, Denefle P, Agid Y, Brice A (1999) A wide variety of mutations in the parkin gene are responsible for autosomal recessive parkinsonism in Europe. French Parkinson's Disease Genetics Study Group and the European Consortium on Genetic Susceptibility in Parkinson's Disease. Hum Mol Genet 8:567-574.

Aharon-Peretz J, Rosenbaum H, Gershoni-Baruch R (2004) Mutations in the glucocerebrosidase gene and Parkinson's disease in Ashkenazi Jews. N Engl J Med 351:1972-1977.

Ahn TB, Kim SY, Kim JY, Park SS, Lee DS, Min HJ, Kim YK, Kim SE, Kim JM, Kim HJ, Cho J, Jeon BS (2008) alpha-Synuclein gene duplication is present in sporadic Parkinson disease. Neurology 70:43-49.

Alves G, Kurz M, Lie SA, Larsen JP (2004) Cigarette smoking in Parkinson's disease: influence on disease progression. Mov Disord 19:1087-1092.

Amezcua L, Chung RH, Conti DV, Langer-Gould AM (2012) Vitamin D levels in Hispanics with multiple sclerosis. J Neurol 259:2565-2570.

Ando M, Funayama M, Li Y, Kashihara K, Murakami Y, Ishizu N, Toyoda C, Noguchi K, Hashimoto T, Nakano N, Sasaki R, Kokubo Y, Kuzuhara S, Ogaki K, Yamashita C, Yoshino H, Hatano T, Tomiyama H, Hattori N (2012) VPS35 mutation in Japanese patients with typical Parkinson's disease. Mov Disord 27:1413-1417.

Arai H, Miyamoto K, Taketani Y, Yamamoto H, Iemori Y, Morita K, Tonai T, Nishisho T, Mori S, Takeda E (1997) A vitamin D receptor gene polymorphism in the translation initiation codon: effect on protein activity and relation to bone mineral density in Japanese women. J Bone Miner Res 12:915-921.

Ariga H, Takahashi-Niki K, Kato I, Maita H, Niki T, Iguchi-Ariga SM (2013) Neuroprotective function of DJ-1 in Parkinson's disease. Oxid Med Cell Longev 2013:683920.

Ascherio A, Munger KL, Simon KC (2010) Vitamin D and multiple sclerosis. Lancet Neurol 9:599-612.

Balicza P, Bereznai B, Takats A, Klivenyi P, Dibo G, Hidasi E, Balogh I, Molnar MJ (2012) [The absence of the common LRRK2 G2019S mutation in 120 young onset Hungarian Parkinon's disease patients]. Ideggyogy Sz 65:239-242.

Beutler E, Gelbart T, Scott CR (2005) Hematologically important mutations: Gaucher disease. Blood Cells Mol Dis 35:355-364.

Bonifacino JS, Hurley JH (2008) Retromer. Curr Opin Cell Biol 20:427-436. 
Bonifati V, Breedveld GJ, Squitieri F, Vanacore N, Brustenghi P, Harhangi BS, Montagna P, Cannella M, Fabbrini G, Rizzu P, van Duijn CM, Oostra BA, Meco G, Heutink P (2002) Localization of autosomal recessive early-onset parkinsonism to chromosome 1p36 (PARK7) in an independent dataset. Ann Neurol 51:253-256.

Bonifati V, Rizzu P, Squitieri F, Krieger E, Vanacore N, van Swieten JC, Brice A, van Duijn CM, Oostra B, Meco G, Heutink P (2003) DJ-1( PARK7), a novel gene for autosomal recessive, early onset parkinsonism. Neurol Sci 24:159-160.

Bonifati V, Rohe CF, Breedveld GJ, Fabrizio E, De Mari M, Tassorelli C, Tavella A, Marconi R, Nicholl DJ, Chien HF, Fincati E, Abbruzzese G, Marini P, De Gaetano A, Horstink MW, Maat-Kievit JA, Sampaio C, Antonini A, Stocchi F, Montagna P, Toni V, Guidi M, Dalla Libera A, Tinazzi M, De Pandis F, Fabbrini G, Goldwurm S, de Klein A, Barbosa E, Lopiano L, Martignoni E, Lamberti P, Vanacore N, Meco G, Oostra BA, Italian Parkinson Genetics N (2005) Early-onset parkinsonism associated with PINK1 mutations: frequency, genotypes, and phenotypes. Neurology 65:87-95.

Bras J, Paisan-Ruiz C, Guerreiro R, Ribeiro MH, Morgadinho A, Januario C, Sidransky E, Oliveira C, Singleton A (2009) Complete screening for glucocerebrosidase mutations in Parkinson disease patients from Portugal. Neurobiol Aging 30:1515-1517.

Brockmann K, Berg D (2014) The significance of GBA for Parkinson's disease. J Inherit Metab Dis 37:643-648.

Buell JS, Dawson-Hughes B, Scott TM, Weiner DE, Dallal GE, Qui WQ, Bergethon P, Rosenberg IH, Folstein MF, Patz S, Bhadelia RA, Tucker KL (2010) 25Hydroxyvitamin D, dementia, and cerebrovascular pathology in elders receiving home services. Neurology 74:18-26.

Burbulla LF, Kruger R (2011) Converging environmental and genetic pathways in the pathogenesis of Parkinson's disease. J Neurol Sci 306:1-8.

Butler MW, Burt A, Edwards TL, Zuchner S, Scott WK, Martin ER, Vance JM, Wang L (2011) Vitamin D receptor gene as a candidate gene for Parkinson disease. Ann Hum Genet 75:201-210.

Cannell JJ (2008) Autism and vitamin D. Med Hypotheses 70:750-759.

Chartier-Harlin MC, Kachergus J, Roumier C, Mouroux V, Douay X, Lincoln S, Levecque C, Larvor L, Andrieux J, Hulihan M, Waucquier N, Defebvre L, Amouyel P, Farrer M, Destee A (2004) Alpha-synuclein locus duplication as a cause of familial Parkinson's disease. Lancet 364:1167-1169.

Choi W, Zibaee S, Jakes R, Serpell LC, Davletov B, Crowther RA, Goedert M (2004) Mutation E46K increases phospholipid binding and assembly into filaments of human alphasynuclein. FEBS Lett 576:363-368.

Clark LN, Nicolai A, Afridi S, Harris J, Mejia-Santana H, Strug L, Cote LJ, Louis ED, Andrews H, Waters C, Ford B, Frucht S, Fahn S, Mayeux R, Ottman R, Marder K (2005) Pilot 
association study of the beta-glucocerebrosidase N370S allele and Parkinson's disease in subjects of Jewish ethnicity. Mov Disord 20:100-103.

Clark LN, Ross BM, Wang Y, Mejia-Santana H, Harris J, Louis ED, Cote LJ, Andrews H, Fahn S, Waters C, Ford B, Frucht S, Ottman R, Marder K (2007) Mutations in the glucocerebrosidase gene are associated with early-onset Parkinson disease. Neurology 69:1270-1277.

Conway KA, Harper JD, Lansbury PT (1998) Accelerated in vitro fibril formation by a mutant alpha-synuclein linked to early-onset Parkinson disease. Nat Med 4:1318-1320.

Coppede F (2012) Genetics and epigenetics of Parkinson's disease. ScientificWorldJournal 2012:489830.

Dai Y, Wu Y, Li Y (2015) Genetic association of cyclooxygenase-2 gene polymorphisms with Parkinson's disease susceptibility in Chinese Han population. Int J Clin Exp Pathol 8:13495-13499.

Dandana A, Ben Khelifa S, Chahed H, Miled A, Ferchichi S (2016) Gaucher Disease: Clinical, Biological and Therapeutic Aspects. Pathobiology 83:13-23.

Dawson TM, Dawson VL (2010) The role of parkin in familial and sporadic Parkinson's disease. Mov Disord 25 Suppl 1:S32-39.

De Marco EV, Annesi G, Tarantino P, Rocca FE, Provenzano G, Civitelli D, Ciro Candiano IC, Annesi F, Carrideo S, Condino F, Nicoletti G, Messina D, Novellino F, Morelli M, Quattrone A (2008) Glucocerebrosidase gene mutations are associated with Parkinson's disease in southern Italy. Mov Disord 23:460-463.

Deng H, Gao K, Jankovic J (2013) The VPS35 gene and Parkinson's disease. Mov Disord 28:569-575.

Di Fonzo A, Wu-Chou YH, Lu CS, van Doeselaar M, Simons EJ, Rohe CF, Chang HC, Chen RS, Weng YH, Vanacore N, Breedveld GJ, Oostra BA, Bonifati V (2006) A common missense variant in the LRRK2 gene, Gly2385Arg, associated with Parkinson's disease risk in Taiwan. Neurogenetics 7:133-138.

Dusso AS, Brown AJ, Slatopolsky E (2005) Vitamin D. Am J Physiol Renal Physiol 289:F828.

Evatt ML, Delong MR, Khazai N, Rosen A, Triche S, Tangpricha V (2008) Prevalence of vitamin d insufficiency in patients with Parkinson disease and Alzheimer disease. Arch Neurol 65:1348-1352.

Eyles DW, Smith S, Kinobe R, Hewison M, McGrath JJ (2005) Distribution of the vitamin D receptor and 1 alpha-hydroxylase in human brain. J Chem Neuroanat 29:21-30.

Farrer M, Kachergus J, Forno L, Lincoln S, Wang DS, Hulihan M, Maraganore D, GwinnHardy K, Wszolek Z, Dickson D, Langston JW (2004) Comparison of kindreds with parkinsonism and alpha-synuclein genomic multiplications. Ann Neurol 55:174-179. 
Farrer MJ, Stone JT, Lin CH, Dachsel JC, Hulihan MM, Haugarvoll K, Ross OA, Wu RM (2007) Lrrk2 G2385R is an ancestral risk factor for Parkinson's disease in Asia. Parkinsonism Relat Disord 13:89-92.

Fink HA, Kuskowski MA, Orwoll ES, Cauley JA, Ensrud KE (2005) Association between Parkinson's disease and low bone density and falls in older men: the osteoporotic fractures in men study. J Am Geriatr Soc 53:1559-1564.

Funayama M, Hasegawa K, Kowa H, Saito M, Tsuji S, Obata F (2002) A new locus for Parkinson's disease (PARK8) maps to chromosome 12p11.2-q13.1. Ann Neurol 51:296301.

Funayama M, Li Y, Tomiyama H, Yoshino H, Imamichi Y, Yamamoto M, Murata M, Toda T, Mizuno Y, Hattori N (2007) Leucine-rich repeat kinase 2 G2385R variant is a risk factor for Parkinson disease in Asian population. Neuroreport 18:273-275.

Gan-Or Z, Giladi N, Rozovski U, Shifrin C, Rosner S, Gurevich T, Bar-Shira A, Orr-Urtreger A (2008) Genotype-phenotype correlations between GBA mutations and Parkinson disease risk and onset. Neurology 70:2277-2283.

Gatto NM, Cockburn M, Bronstein J, Manthripragada AD, Ritz B (2009) Well-water consumption and Parkinson's disease in rural California. Environ Health Perspect 117:1912-1918.

Gegg ME, Burke D, Heales SJ, Cooper JM, Hardy J, Wood NW, Schapira AH (2012) Glucocerebrosidase deficiency in substantia nigra of parkinson disease brains. Ann Neurol 72:455-463.

Gegg ME, Schapira AHV (2018) The role of glucocerebrosidase in Parkinson disease pathogenesis. The FEBS journal.

Goker-Alpan O, Schiffmann R, LaMarca ME, Nussbaum RL, McInerney-Leo A, Sidransky E (2004) Parkinsonism among Gaucher disease carriers. J Med Genet 41:937-940.

Gonzalez-Del Rincon Mde L, Monroy Jaramillo N, Suarez Martinez AI, Yescas Gomez P, Boll Woehrlen MC, Lopez Lopez M, Alonso Vilatela ME (2013) The L444P GBA mutation is associated with early-onset Parkinson's disease in Mexican Mestizos. Clin Genet 84:386-387.

Gorell JM, Johnson CC, Rybicki BA, Peterson EL, Richardson RJ (1998) The risk of Parkinson's disease with exposure to pesticides, farming, well water, and rural living. Neurology 50:1346-1350.

Gorell JM, Rybicki BA, Johnson CC, Peterson EL (1999) Smoking and Parkinson's disease: a dose-response relationship. Neurology 52:115-119.

Goris A, Williams-Gray CH, Clark GR, Foltynie T, Lewis SJ, Brown J, Ban M, Spillantini MG, Compston A, Burn DJ, Chinnery PF, Barker RA, Sawcer SJ (2007) Tau and alphasynuclein in susceptibility to, and dementia in, Parkinson's disease. Ann Neurol 62:145153. 
Han F, Grimes DA, Li F, Wang T, Yu Z, Song N, Wu S, Racacho L, Bulman DE (2016) Mutations in the glucocerebrosidase gene are common in patients with Parkinson's disease from Eastern Canada. Int J Neurosci 126:415-421.

Han X, Xue L, Li Y, Chen B, Xie A (2012) Vitamin D receptor gene polymorphism and its association with Parkinson's disease in Chinese Han population. Neurosci Lett 525:2933.

Harris SS, Eccleshall TR, Gross C, Dawson-Hughes B, Feldman D (1997) The vitamin D receptor start codon polymorphism (FokI) and bone mineral density in premenopausal American black and white women. J Bone Miner Res 12:1043-1048.

Healy DG, Falchi M, O'Sullivan SS, Bonifati V, Durr A, Bressman S, Brice A, Aasly J, Zabetian CP, Goldwurm S, Ferreira JJ, Tolosa E, Kay DM, Klein C, Williams DR, Marras C, Lang AE, Wszolek ZK, Berciano J, Schapira AH, Lynch T, Bhatia KP, Gasser T, Lees AJ, Wood NW, International LC (2008) Phenotype, genotype, and worldwide genetic penetrance of LRRK2-associated Parkinson's disease: a case-control study. Lancet Neurol 7:583-590.

Hedrich K, Eskelson C, Wilmot B, Marder K, Harris J, Garrels J, Meija-Santana H, Vieregge P, Jacobs H, Bressman SB, Lang AE, Kann M, Abbruzzese G, Martinelli P, Schwinger E, Ozelius LJ, Pramstaller PP, Klein C, Kramer P (2004) Distribution, type, and origin of Parkin mutations: review and case studies. Mov Disord 19:1146-1157.

Hruska KS, Goker-Alpan O, Sidransky E (2006) Gaucher disease and the synucleinopathies. J Biomed Biotechnol 2006:78549.

Hruska KS, LaMarca ME, Scott CR, Sidransky E (2008) Gaucher disease: mutation and polymorphism spectrum in the glucocerebrosidase gene (GBA). Hum Mutat 29:567583.

Hutton M, Lendon CL, Rizzu P, Baker M, Froelich S, Houlden H, Pickering-Brown S, Chakraverty S, Isaacs A, Grover A, Hackett J, Adamson J, Lincoln S, Dickson D, Davies P, Petersen RC, Stevens M, de Graaff E, Wauters E, van Baren J, Hillebrand M, Joosse M, Kwon JM, Nowotny P, Che LK, Norton J, Morris JC, Reed LA, Trojanowski J, Basun H, Lannfelt L, Neystat M, Fahn S, Dark F, Tannenberg T, Dodd PR, Hayward N, Kwok JB, Schofield PR, Andreadis A, Snowden J, Craufurd D, Neary D, Owen F, Oostra BA, Hardy J, Goate A, van Swieten J, Mann D, Lynch T, Heutink P (1998) Association of missense and 5'-splice-site mutations in tau with the inherited dementia FTDP-17. Nature 393:702-705.

Ibanez P, Lesage S, Lohmann E, Thobois S, De Michele G, Borg M, Agid Y, Durr A, Brice A, French Parkinson's Disease Genetics Study G (2006) Mutational analysis of the PINK1 gene in early-onset parkinsonism in Europe and North Africa. Brain 129:686-694.

Jankovic J (2005) Searching for a relationship between manganese and welding and Parkinson's disease. Neurology 64:2021-2028.

Jellinger KA (1991) Pathology of Parkinson's disease. Changes other than the nigrostriatal pathway. Mol Chem Neuropathol 14:153-197. 
Jo E, McLaurin J, Yip CM, St George-Hyslop P, Fraser PE (2000) alpha-Synuclein membrane interactions and lipid specificity. J Biol Chem 275:34328-34334.

Johnson J, Hague SM, Hanson M, Gibson A, Wilson KE, Evans EW, Singleton AA, McInerney-Leo A, Nussbaum RL, Hernandez DG, Gallardo M, McKeith IG, Burn DJ, Ryu M, Hellstrom O, Ravina B, Eerola J, Perry RH, Jaros E, Tienari P, Weiser R, Gwinn-Hardy K, Morris CM, Hardy J, Singleton AB (2004) SNCA multiplication is not a common cause of Parkinson disease or dementia with Lewy bodies. Neurology 63:554-556.

Kalinderi K, Bostantjopoulou S, Fidani L (2016) The genetic background of Parkinson's disease: current progress and future prospects. Acta Neurol Scand.

Kalinderi K, Bostantjopoulou S, Katsarou Z, Dimikiotou M, Fidani L (2015) D620N mutation in the VPS35 gene and R1205H mutation in the EIF4G1 gene are uncommon in the Greek population. Neurosci Lett 606:113-116.

Kalinderi K, Bostantjopoulou S, Paisan-Ruiz C, Katsarou Z, Hardy J, Fidani L (2009) Complete screening for glucocerebrosidase mutations in Parkinson disease patients from Greece. Neurosci Lett 452:87-89.

Kato S (2000) The function of vitamin D receptor in vitamin D action. J Biochem 127:717-722.

Kesby JP, Eyles DW, Burne TH, McGrath JJ (2011) The effects of vitamin D on brain development and adult brain function. Mol Cell Endocrinol 347:121-127.

Kim JM, Lee JY, Kim HJ, Kim JS, Shin ES, Cho JH, Park SS, Jeon BS (2010) The LRRK2 G2385R variant is a risk factor for sporadic Parkinson's disease in the Korean population. Parkinsonism Relat Disord 16:85-88.

Kim JS, Kim YI, Song C, Yoon I, Park JW, Choi YB, Kim HT, Lee KS (2005) Association of vitamin D receptor gene polymorphism and Parkinson's disease in Koreans. J Korean Med Sci 20:495-498.

Kitada T, Asakawa S, Hattori N, Matsumine H, Yamamura Y, Minoshima S, Yokochi M, Mizuno Y, Shimizu N (1998) Mutations in the parkin gene cause autosomal recessive juvenile parkinsonism. Nature 392:605-608.

Knekt P, Kilkkinen A, Rissanen H, Marniemi J, Saaksjarvi K, Heliovaara M (2010) Serum vitamin D and the risk of Parkinson disease. Arch Neurol 67:808-811.

Kruger R, Kuhn W, Muller T, Woitalla D, Graeber M, Kosel S, Przuntek H, Epplen JT, Schols L, Riess O (1998) Ala30Pro mutation in the gene encoding alpha-synuclein in Parkinson's disease. Nat Genet 18:106-108.

Kumar KR, Ramirez A, Gobel A, Kresojevic N, Svetel M, Lohmann K, C MS, Rolfs A, Mazzulli JR, Alcalay RN, Krainc D, Klein C, Kostic V, Grunewald A (2013) Glucocerebrosidase mutations in a Serbian Parkinson's disease population. Eur J Neurol 20:402-405. 
Kumar KR, Weissbach A, Heldmann M, Kasten M, Tunc S, Sue CM, Svetel M, Kostic VS, Segura-Aguilar J, Ramirez A, Simon DK, Vieregge P, Munte TF, Hagenah J, Klein C, Lohmann K (2012) Frequency of the D620N mutation in VPS35 in Parkinson disease. Arch Neurol 69:1360-1364.

Labbe C, Ross OA (2014) Association studies of sporadic Parkinson's disease in the genomic era. Curr Genomics 15:2-10.

Lange J, Lunde KA, Sletten C, Moller SG, Tysnes OB, Alves G, Larsen JP, Maple-Grodem J (2015) Association of a BACE1 Gene Polymorphism with Parkinson's Disease in a Norwegian Population. Parkinsons Dis 2015:973298.

Langston JW, Ballard P, Tetrud JW, Irwin I (1983) Chronic Parkinsonism in humans due to a product of meperidine-analog synthesis. Science 219:979-980.

Lesage S, Anheim M, Condroyer C, Pollak P, Durif F, Dupuits C, Viallet F, Lohmann E, Corvol JC, Honore A, Rivaud S, Vidailhet M, Durr A, Brice A, French Parkinson's Disease Genetics Study G (2011) Large-scale screening of the Gaucher's disease-related glucocerebrosidase gene in Europeans with Parkinson's disease. Hum Mol Genet 20:202-210.

Lesage S, Condroyer C, Klebe S, Honore A, Tison F, Brefel-Courbon C, Durr A, Brice A (2012) Identification of VPS35 mutations replicated in French families with Parkinson disease. Neurology 78:1449-1450.

Li Y, Li P, Liang H, Zhao Z, Hashimoto M, Wei J (2015) Gaucher-Associated Parkinsonism. Cell Mol Neurobiol 35:755-761.

Lin $\mathrm{CH}$, Chen KH, Chen ML, Lin HI, Wu RM (2014) Vitamin D receptor genetic variants and Parkinson's disease in a Taiwanese population. Neurobiol Aging 35:1212 e1211-1213.

Linhart R, Wong SA, Cao J, Tran M, Huynh A, Ardrey C, Park JM, Hsu C, Taha S, Peterson R, Shea S, Kurian J, Venderova K (2014) Vacuolar protein sorting 35 (Vps35) rescues locomotor deficits and shortened lifespan in Drosophila expressing a Parkinson's disease mutant of Leucine-Rich Repeat Kinase 2 (LRRK2). Mol Neurodegener 9:23.

Liu J, Sun QY, Tang BS, Hu L, Yu RH, Wang L, Shi CH, Yan XX, Pan Q, Xia K, Guo JF (2011) PITX3 gene polymorphism is associated with Parkinson's disease in Chinese population. Brain Res 1392:116-120.

Lubbe S, Morris HR (2014) Recent advances in Parkinson's disease genetics. J Neurol 261:259266.

Ludolph AC, Kassubek J, Landwehrmeyer BG, Mandelkow E, Mandelkow EM, Burn DJ, Caparros-Lefebvre D, Frey KA, de Yebenes JG, Gasser T, Heutink P, Hoglinger G, Jamrozik Z, Jellinger KA, Kazantsev A, Kretzschmar H, Lang AE, Litvan I, Lucas JJ, McGeer PL, Melquist S, Oertel W, Otto M, Paviour D, Reum T, Saint-Raymond A, Steele JC, Tolnay M, Tumani H, van Swieten JC, Vanier MT, Vonsattel JP, Wagner S, Wszolek ZK, Reisensburg Working Group for Tauopathies With P (2009) Tauopathies 
with parkinsonism: clinical spectrum, neuropathologic basis, biological markers, and treatment options. Eur J Neurol 16:297-309.

Mao XY, Burgunder JM, Zhang ZJ, An XK, Zhang JH, Yang Y, Li T, Wang YC, Chang XL, Peng R (2010) Association between GBA L444P mutation and sporadic Parkinson's disease from Mainland China. Neurosci Lett 469:256-259.

Maraganore DM, de Andrade M, Elbaz A, Farrer MJ, Ioannidis JP, Kruger R, Rocca WA, Schneider NK, Lesnick TG, Lincoln SJ, Hulihan MM, Aasly JO, Ashizawa T, ChartierHarlin MC, Checkoway H, Ferrarese C, Hadjigeorgiou G, Hattori N, Kawakami H, Lambert JC, Lynch T, Mellick GD, Papapetropoulos S, Parsian A, Quattrone A, Riess O, Tan EK, Van Broeckhoven C, Genetic Epidemiology of Parkinson's Disease C (2006) Collaborative analysis of alpha-synuclein gene promoter variability and Parkinson disease. JAMA 296:661-670.

McGrath J (1999) Hypothesis: is low prenatal vitamin D a risk-modifying factor for schizophrenia? Schizophr Res 40:173-177.

McNeill A, Magalhaes J, Shen C, Chau KY, Hughes D, Mehta A, Foltynie T, Cooper JM, Abramov AY, Gegg M, Schapira AH (2014) Ambroxol improves lysosomal biochemistry in glucocerebrosidase mutation-linked Parkinson disease cells. Brain 137:1481-1495.

Miller SA, Dykes DD, Polesky HF (1988) A simple salting out procedure for extracting DNA from human nucleated cells. Nucleic Acids Res 16:1215.

Mitsui J, Mizuta I, Toyoda A, Ashida R, Takahashi Y, Goto J, Fukuda Y, Date H, Iwata A, Yamamoto M, Hattori N, Murata M, Toda T, Tsuji S (2009) Mutations for Gaucher disease confer high susceptibility to Parkinson disease. Arch Neurol 66:571-576.

Moraitou M, Hadjigeorgiou G, Monopolis I, Dardiotis E, Bozi M, Vassilatis D, Vilageliu L, Grinberg D, Xiromerisiou G, Stefanis L, Michelakakis H (2011) betaGlucocerebrosidase gene mutations in two cohorts of Greek patients with sporadic Parkinson's disease. Mol Genet Metab 104:149-152.

Mowry EM (2011) Vitamin D: evidence for its role as a prognostic factor in multiple sclerosis. J Neurol Sci 311:19-22.

Muangpaisan W, Mathews A, Hori H, Seidel D (2011) A systematic review of the worldwide prevalence and incidence of Parkinson's disease. J Med Assoc Thai 94:749-755.

Mueller JC, Fuchs J, Hofer A, Zimprich A, Lichtner P, Illig T, Berg D, Wullner U, Meitinger T, Gasser T (2005) Multiple regions of alpha-synuclein are associated with Parkinson's disease. Ann Neurol 57:535-541.

Munger KL, Levin LI, Hollis BW, Howard NS, Ascherio A (2006) Serum 25-hydroxyvitamin D levels and risk of multiple sclerosis. JAMA 296:2832-2838. 
Neudorfer O, Giladi N, Elstein D, Abrahamov A, Turezkite T, Aghai E, Reches A, Bembi B, Zimran A (1996) Occurrence of Parkinson's syndrome in type I Gaucher disease. QJM 89:691-694.

Neumann J, Bras J, Deas E, O'Sullivan SS, Parkkinen L, Lachmann RH, Li A, Holton J, Guerreiro R, Paudel R, Segarane B, Singleton A, Lees A, Hardy J, Houlden H, Revesz T, Wood NW (2009) Glucocerebrosidase mutations in clinical and pathologically proven Parkinson's disease. Brain 132:1783-1794.

Newmark HL, Newmark J (2007) Vitamin D and Parkinson's disease--a hypothesis. Mov Disord 22:461-468.

Nishioka K, Hayashi S, Farrer MJ, Singleton AB, Yoshino H, Imai H, Kitami T, Sato K, Kuroda R, Tomiyama H, Mizoguchi K, Murata M, Toda T, Imoto I, Inazawa J, Mizuno Y, Hattori N (2006) Clinical heterogeneity of alpha-synuclein gene duplication in Parkinson's disease. Ann Neurol 59:298-309.

Niu MY, Wang L, Xie AM (2015) ApaI, BsmI, FokI, and TaqI Polymorphisms in the Vitamin D Receptor Gene and Parkinson's Disease. Chin Med J (Engl) 128:1809-1814.

Ortega RA, Torres PA, Swan M, Nichols W, Boschung S, Raymond D, Barrett MJ, Johannes BA, Severt L, Shanker V, Hunt AL, Bressman S, Pastores GM, Saunders-Pullman R (2016) Glucocerebrosidase enzyme activity in GBA mutation Parkinson's disease. J Clin Neurosci.

Orton SM, Ramagopalan SV, Para AE, Lincoln MR, Handunnetthi L, Chao MJ, Morahan J, Morrison KM, Sadovnick AD, Ebers GC (2011) Vitamin D metabolic pathway genes and risk of multiple sclerosis in Canadians. J Neurol Sci 305:116-120.

Pals P, Lincoln S, Manning J, Heckman M, Skipper L, Hulihan M, Van den Broeck M, De Pooter T, Cras P, Crook J, Van Broeckhoven C, Farrer MJ (2004) alpha-Synuclein promoter confers susceptibility to Parkinson's disease. Ann Neurol 56:591-595.

Parkinson J (2002) An essay on the shaking palsy. 1817. J Neuropsychiatry Clin Neurosci 14:223-236; discussion 222.

Pastor P, Ezquerra M, Munoz E, Marti MJ, Blesa R, Tolosa E, Oliva R (2000) Significant association between the tau gene A0/A0 genotype and Parkinson's disease. Ann Neurol 47:242-245.

Petersen MS, Bech S, Christiansen DH, Schmedes AV, Halling J (2014) The role of vitamin D levels and vitamin D receptor polymorphism on Parkinson's disease in the Faroe Islands. Neurosci Lett 561:74-79.

Pfeiffer RF (2016) Non-motor symptoms in Parkinson's disease. Parkinsonism Relat Disord 22 Suppl 1:S119-122.

Polymeropoulos MH, Higgins JJ, Golbe LI, Johnson WG, Ide SE, Di Iorio G, Sanges G, Stenroos ES, Pho LT, Schaffer AA, Lazzarini AM, Nussbaum RL, Duvoisin RC (1996) 
Mapping of a gene for Parkinson's disease to chromosome 4q21-q23. Science 274:11971199.

Polymeropoulos MH, Lavedan C, Leroy E, Ide SE, Dehejia A, Dutra A, Pike B, Root H, Rubenstein J, Boyer R, Stenroos ES, Chandrasekharappa S, Athanassiadou A, Papapetropoulos T, Johnson WG, Lazzarini AM, Duvoisin RC, Di Iorio G, Golbe LI, Nussbaum RL (1997) Mutation in the alpha-synuclein gene identified in families with Parkinson's disease. Science 276:2045-2047.

Pringsheim T, Jette N, Frolkis A, Steeves TD (2014) The prevalence of Parkinson's disease: a systematic review and meta-analysis. Mov Disord 29:1583-1590.

Riggs BL, Nguyen TV, Melton LJ, 3rd, Morrison NA, O'Fallon WM, Kelly PJ, Egan KS, Sambrook PN, Muhs JM, Eisman JA (1995) The contribution of vitamin D receptor gene alleles to the determination of bone mineral density in normal and osteoporotic women. J Bone Miner Res 10:991-996.

Ross OA, Soto-Ortolaza AI, Heckman MG, Aasly JO, Abahuni N, Annesi G, Bacon JA, Bardien S, Bozi M, Brice A, Brighina L, Van Broeckhoven C, Carr J, Chartier-Harlin MC, Dardiotis E, Dickson DW, Diehl NN, Elbaz A, Ferrarese C, Ferraris A, Fiske B, Gibson JM, Gibson R, Hadjigeorgiou GM, Hattori N, Ioannidis JP, Jasinska-Myga B, Jeon BS, Kim YJ, Klein C, Kruger R, Kyratzi E, Lesage S, Lin CH, Lynch T, Maraganore DM, Mellick GD, Mutez E, Nilsson C, Opala G, Park SS, Puschmann A, Quattrone A, Sharma M, Silburn PA, Sohn YH, Stefanis L, Tadic V, Theuns J, Tomiyama H, Uitti RJ, Valente EM, van de Loo S, Vassilatis DK, Vilarino-Guell C, White LR, Wirdefeldt K, Wszolek ZK, Wu RM, Farrer MJ, Genetic Epidemiology Of Parkinson's Disease C (2011) Association of LRRK2 exonic variants with susceptibility to Parkinson's disease: a case-control study. Lancet Neurol 10:898-908.

Sainz J, Van Tornout JM, Loro ML, Sayre J, Roe TF, Gilsanz V (1997) Vitamin D-receptor gene polymorphisms and bone density in prepubertal American girls of Mexican descent. N Engl J Med 337:77-82.

Sato C, Morgan A, Lang AE, Salehi-Rad S, Kawarai T, Meng Y, Ray PN, Farrer LA, St GeorgeHyslop P, Rogaeva E (2005a) Analysis of the glucocerebrosidase gene in Parkinson's disease. Mov Disord 20:367-370.

Sato Y, Asoh T, Oizumi K (1998) High prevalence of vitamin D deficiency and reduced bone mass in elderly women with Alzheimer's disease. Bone 23:555-557.

Sato Y, Honda Y, Iwamoto J, Kanoko T, Satoh K (2005b) Abnormal bone and calcium metabolism in immobilized Parkinson's disease patients. Mov Disord 20:1598-1603.

Sato Y, Kikuyama M, Oizumi K (1997) High prevalence of vitamin D deficiency and reduced bone mass in Parkinson's disease. Neurology 49:1273-1278.

Schapira AH (2015) Glucocerebrosidase and Parkinson disease: Recent advances. Mol Cell Neurosci. 
Schulte C, Gasser T (2011) Genetic basis of Parkinson's disease: inheritance, penetrance, and expression. Appl Clin Genet 4:67-80.

Seto-Salvia N, Pagonabarraga J, Houlden H, Pascual-Sedano B, Dols-Icardo O, Tucci A, Paisan-Ruiz C, Campolongo A, Anton-Aguirre S, Martin I, Munoz L, Bufill E, Vilageliu L, Grinberg D, Cozar M, Blesa R, Lleo A, Hardy J, Kulisevsky J, Clarimon J (2012) Glucocerebrosidase mutations confer a greater risk of dementia during Parkinson's disease course. Mov Disord 27:393-399.

Sharma M, Ioannidis JP, Aasly JO, Annesi G, Brice A, Bertram L, Bozi M, Barcikowska M, Crosiers D, Clarke CE, Facheris MF, Farrer M, Garraux G, Gispert S, Auburger G, Vilarino-Guell C, Hadjigeorgiou GM, Hicks AA, Hattori N, Jeon BS, Jamrozik Z, Krygowska-Wajs A, Lesage S, Lill CM, Lin JJ, Lynch T, Lichtner P, Lang AE, Libioulle C, Murata M, Mok V, Jasinska-Myga B, Mellick GD, Morrison KE, Meitnger T, Zimprich A, Opala G, Pramstaller PP, Pichler I, Park SS, Quattrone A, Rogaeva E, Ross OA, Stefanis L, Stockton JD, Satake W, Silburn PA, Strom TM, Theuns J, Tan EK, Toda T, Tomiyama H, Uitti RJ, Van Broeckhoven C, Wirdefeldt K, Wszolek Z, Xiromerisiou G, Yomono HS, Yueh KC, Zhao Y, Gasser T, Maraganore D, Kruger R, consortium G (2012) A multi-centre clinico-genetic analysis of the VPS35 gene in Parkinson disease indicates reduced penetrance for disease-associated variants. J Med Genet 49:721-726.

Sheerin UM, Charlesworth G, Bras J, Guerreiro R, Bhatia K, Foltynie T, Limousin P, SilveiraMoriyama L, Lees A, Wood N (2012) Screening for VPS35 mutations in Parkinson's disease. Neurobiol Aging 33:838 e831-835.

Shimura H, Hattori N, Kubo S, Mizuno Y, Asakawa S, Minoshima S, Shimizu N, Iwai K, Chiba T, Tanaka K, Suzuki T (2000) Familial Parkinson disease gene product, parkin, is a ubiquitin-protein ligase. Nat Genet 25:302-305.

Sidransky E, Nalls MA, Aasly JO, Aharon-Peretz J, Annesi G, Barbosa ER, Bar-Shira A, Berg D, Bras J, Brice A, Chen CM, Clark LN, Condroyer C, De Marco EV, Durr A, Eblan MJ, Fahn S, Farrer MJ, Fung HC, Gan-Or Z, Gasser T, Gershoni-Baruch R, Giladi N, Griffith A, Gurevich T, Januario C, Kropp P, Lang AE, Lee-Chen GJ, Lesage S, Marder K, Mata IF, Mirelman A, Mitsui J, Mizuta I, Nicoletti G, Oliveira C, Ottman R, OrrUrtreger A, Pereira LV, Quattrone A, Rogaeva E, Rolfs A, Rosenbaum H, Rozenberg R, Samii A, Samaddar T, Schulte C, Sharma M, Singleton A, Spitz M, Tan EK, Tayebi N, Toda T, Troiano AR, Tsuji S, Wittstock M, Wolfsberg TG, Wu YR, Zabetian CP, Zhao Y, Ziegler SG (2009) Multicenter analysis of glucocerebrosidase mutations in Parkinson's disease. N Engl J Med 361:1651-1661.

Singer TP, Ramsay RR (1990) Mechanism of the neurotoxicity of MPTP. An update. FEBS Lett 274:1-8.

Skipper L, Wilkes K, Toft M, Baker M, Lincoln S, Hulihan M, Ross OA, Hutton M, Aasly J, Farrer M (2004) Linkage disequilibrium and association of MAPT H1 in Parkinson disease. Am J Hum Genet 75:669-677. 
Small SA, Kent K, Pierce A, Leung C, Kang MS, Okada H, Honig L, Vonsattel JP, Kim TW (2005) Model-guided microarray implicates the retromer complex in Alzheimer's disease. Ann Neurol 58:909-919.

Stefansson H, Helgason A, Thorleifsson G, Steinthorsdottir V, Masson G, Barnard J, Baker A, Jonasdottir A, Ingason A, Gudnadottir VG, Desnica N, Hicks A, Gylfason A, Gudbjartsson DF, Jonsdottir GM, Sainz J, Agnarsson K, Birgisdottir B, Ghosh S, Olafsdottir A, Cazier JB, Kristjansson K, Frigge ML, Thorgeirsson TE, Gulcher JR, Kong A, Stefansson K (2005) A common inversion under selection in Europeans. Nat Genet 37:129-137.

Sudhaman S, Behari M, Govindappa ST, Muthane UB, Juyal RC, Thelma BK (2013) VPS35 and EIF4G1 mutations are rare in Parkinson's disease among Indians. Neurobiol Aging 34:2442 e2441-2443.

Suzuki M, Yoshioka M, Hashimoto M, Murakami M, Kawasaki K, Noya M, Takahashi D, Urashima M (2012) 25-hydroxyvitamin D, vitamin D receptor gene polymorphisms, and severity of Parkinson's disease. Mov Disord 27:264-271.

Suzuki M, Yoshioka M, Hashimoto M, Murakami M, Noya M, Takahashi D, Urashima M (2013) Randomized, double-blind, placebo-controlled trial of vitamin D supplementation in Parkinson disease. Am J Clin Nutr 97:1004-1013.

Tan EK, Tang M, Tan LC, Wu YR, Wu RM, Ross OA, Zhao Y (2008) Lrrk2 R1628P in nonChinese Asian races. Ann Neurol 64:472-473.

Toft M, Pielsticker L, Ross OA, Aasly JO, Farrer MJ (2006) Glucocerebrosidase gene mutations and Parkinson disease in the Norwegian population. Neurology 66:415-417.

Tsika E, Glauser L, Moser R, Fiser A, Daniel G, Sheerin UM, Lees A, Troncoso JC, Lewis PA, Bandopadhyay R, Schneider BL, Moore DJ (2014) Parkinson's disease-linked mutations in VPS35 induce dopaminergic neurodegeneration. Hum Mol Genet 23:46214638.

Vacic V, Ozelius LJ, Clark LN, Bar-Shira A, Gana-Weisz M, Gurevich T, Gusev A, Kedmi M, Kenny EE, Liu X, Mejia-Santana H, Mirelman A, Raymond D, Saunders-Pullman R, Desnick RJ, Atzmon G, Burns ER, Ostrer H, Hakonarson H, Bergman A, Barzilai N, Darvasi A, Peter I, Guha S, Lencz T, Giladi N, Marder K, Pe'er I, Bressman SB, OrrUrtreger A (2014) Genome-wide mapping of IBD segments in an Ashkenazi PD cohort identifies associated haplotypes. Hum Mol Genet 23:4693-4702.

Valente EM, Abou-Sleiman PM, Caputo V, Muqit MM, Harvey K, Gispert S, Ali Z, Del Turco D, Bentivoglio AR, Healy DG, Albanese A, Nussbaum R, Gonzalez-Maldonado R, Deller T, Salvi S, Cortelli P, Gilks WP, Latchman DS, Harvey RJ, Dallapiccola B, Auburger G, Wood NW (2004) Hereditary early-onset Parkinson's disease caused by mutations in PINK1. Science 304:1158-1160.

Valente EM, Bentivoglio AR, Dixon PH, Ferraris A, Ialongo T, Frontali M, Albanese A, Wood NW (2001) Localization of a novel locus for autosomal recessive early-onset 
parkinsonism, PARK6, on human chromosome 1p35-p36. Am J Hum Genet 68:895900.

van Duijn CM, Dekker MC, Bonifati V, Galjaard RJ, Houwing-Duistermaat JJ, Snijders PJ, Testers L, Breedveld GJ, Horstink M, Sandkuijl LA, van Swieten JC, Oostra BA, Heutink P (2001) Park7, a novel locus for autosomal recessive early-onset parkinsonism, on chromosome 1p36. Am J Hum Genet 69:629-634.

Vilarino-Guell C, Wider C, Ross OA, Dachsel JC, Kachergus JM, Lincoln SJ, Soto-Ortolaza AI, Cobb SA, Wilhoite GJ, Bacon JA, Behrouz B, Melrose HL, Hentati E, Puschmann A, Evans DM, Conibear E, Wasserman WW, Aasly JO, Burkhard PR, Djaldetti R, Ghika J, Hentati F, Krygowska-Wajs A, Lynch T, Melamed E, Rajput A, Rajput AH, Solida A, Wu RM, Uitti RJ, Wszolek ZK, Vingerhoets F, Farrer MJ (2011) VPS35 mutations in Parkinson disease. Am J Hum Genet 89:162-167.

Wang Y, Liu L, Xiong J, Zhang X, Chen Z, Yu L, Chen C, Huang J, Zhang Z, Mohmed AA, Lin Z, Xiong N, Wang T (2012) Glucocerebrosidase L444P mutation confers genetic risk for Parkinson's disease in central China. Behav Brain Funct 8:57.

Williams ET, Chen X, Moore DJ (2017) VPS35, the Retromer Complex and Parkinson's Disease. Journal of Parkinson's disease 7:219-233.

Wong K, Sidransky E, Verma A, Mixon T, Sandberg GD, Wakefield LK, Morrison A, Lwin A, Colegial C, Allman JM, Schiffmann R (2004) Neuropathology provides clues to the pathophysiology of Gaucher disease. Mol Genet Metab 82:192-207.

Wu YR, Chen CM, Chao CY, Ro LS, Lyu RK, Chang KH, Lee-Chen GJ (2007) Glucocerebrosidase gene mutation is a risk factor for early onset of Parkinson disease among Taiwanese. J Neurol Neurosurg Psychiatry 78:977-979.

Zabetian CP, Hutter CM, Factor SA, Nutt JG, Higgins DS, Griffith A, Roberts JW, Leis BC, Kay DM, Yearout D, Montimurro JS, Edwards KL, Samii A, Payami H (2007) Association analysis of MAPT H1 haplotype and subhaplotypes in Parkinson's disease. Ann Neurol 62:137-144.

Zarranz JJ, Alegre J, Gomez-Esteban JC, Lezcano E, Ros R, Ampuero I, Vidal L, Hoenicka J, Rodriguez O, Atares B, Llorens V, Gomez Tortosa E, del Ser T, Munoz DG, de Yebenes JG (2004) The new mutation, E46K, of alpha-synuclein causes Parkinson and Lewy body dementia. Ann Neurol 55:164-173.

Zhang P, Yu L, Gao J, Fu Q, Dai F, Zhao Y, Zheng L, Zhao S (2000) Cloning and characterization of human VPS35 and mouse Vps35 and mapping of VPS35 to human chromosome 16q13-q21. Genomics 70:253-257.

Zhang X, Bao QQ, Zhuang XS, Gan SR, Zhao D, Liu Y, Hu Q, Chen Y, Zhu F, Wang L, Wang N (2012) Association of Common Variants in the Glucocerebrosidase Gene with High Susceptibility to Parkinson's Disease among Chinese. Chin J Physiol 55:398-404. 
Zhang ZT, He YC, Ma XJ, Li DY, Lu GC (2014) Association between vitamin D receptor gene polymorphisms and susceptibility to Parkinson's disease: a meta-analysis. Neurosci Lett 578:122-127.

Zhang ZX, Roman GC (1993) Worldwide occurrence of Parkinson's disease: an updated review. Neuroepidemiology 12:195-208.

Zhou ZD, Refai FS, Xie SP, Ng SH, Chan CH, Ho PG, Zhang XD, Lim TM, Tan EK (2014) Mutant PINK1 upregulates tyrosine hydroxylase and dopamine levels, leading to vulnerability of dopaminergic neurons. Free Radic Biol Med 68:220-233.

Zimprich A, Benet-Pages A, Struhal W, Graf E, Eck SH, Offman MN, Haubenberger D, Spielberger S, Schulte EC, Lichtner P, Rossle SC, Klopp N, Wolf E, Seppi K, Pirker W, Presslauer S, Mollenhauer B, Katzenschlager R, Foki T, Hotzy C, Reinthaler E, Harutyunyan A, Kralovics R, Peters A, Zimprich F, Brucke T, Poewe W, Auff E, Trenkwalder C, Rost B, Ransmayr G, Winkelmann J, Meitinger T, Strom TM (2011) A mutation in VPS35, encoding a subunit of the retromer complex, causes late-onset Parkinson disease. Am J Hum Genet 89:168-175.

Zimprich A, Biskup S, Leitner P, Lichtner P, Farrer M, Lincoln S, Kachergus J, Hulihan M, Uitti RJ, Calne DB, Stoessl AJ, Pfeiffer RF, Patenge N, Carbajal IC, Vieregge P, Asmus F, Muller-Myhsok B, Dickson DW, Meitinger T, Strom TM, Wszolek ZK, Gasser T (2004) Mutations in LRRK2 cause autosomal-dominant parkinsonism with pleomorphic pathology. Neuron 44:601-607.

Zmuda JM, Cauley JA, Ferrell RE (2000) Molecular epidemiology of vitamin D receptor gene variants. Epidemiol Rev 22:203-217. 
I. 


\title{
Association of vitamin $\mathrm{D}$ receptor gene polymorphisms and Parkinson's disease in Hungarians
}

\author{
Rita Török ${ }^{\mathrm{a}}$, Nora Török ${ }^{\mathrm{a}}$, Levente Szalardy ${ }^{\mathrm{a}}$, Imola Plangar ${ }^{\mathrm{a}}$, Zoltan Szolnoki $^{\mathrm{b}}$, \\ Ferenc Somogyvari ${ }^{c}$, Laszlo Vecsei ${ }^{\mathrm{a}, \mathrm{d}}$, Peter Klivenyi ${ }^{\mathrm{a}, *}$ \\ a Department of Neurology, University of Szeged, Semmelweis u. 6., H-6725 Szeged, Hungary \\ b Department of Neurology and Cerebrovascular Diseases, Pándy Kálmán County Hospital, Semmelweis u. 1., H-5700 Gyula, Hungary \\ c Department of Medical Microbiology and Immunology, Faculty of Medicine, University of Szeged, Dóm tér 10., H-6725 Szeged, Hungary \\ ${ }^{\mathrm{d}}$ Neuroscience Research Group of the Hungarian Academy of Sciences and University of Szeged, Semmelweis u. 6., H-6725 Szeged, Hungary
}

\section{H I G H L I G H T S}

- Genotyping for four polymorphic sites in the VDR gene in patients with Parkinson's disease.

- Association was detected between FokI C polymorphism and Parkinson's disease.

- No association could be detected between ApaI, BsmI, TaqI polymorphisms and Parkinson's disease.

\section{A R T I C L E I N F O}

\section{Article history:}

Received 23 April 2013

Received in revised form 24 June 2013

Accepted 5 July 2013

\section{Keywords:}

FokI

Parkinson's disease

Polymorphism

Vitamin D receptor

\begin{abstract}
A B S T R A C T
Vitamin D receptor (VDR) gene encodes a transcription factor that influences calcium homeostasis and immunoregulation, and may play a role in neurological disorders including Parkinson's disease (PD). The investigations of the association between VDR and PD in different populations revealed various results. In a present study $100 \mathrm{PD}$ patients and 109 healthy controls from the Hungarian population were genotyped for four polymorphic sites (BsmI, Apal, FokI and TaqI) in the VDR gene. The polymorphisms were determined by polymerase chain reaction and restriction fragment length polymorphism (PCRRFLP). Our results demonstrate an association between the FokI $C$ allele and PD; the frequency of the $C$ allele was significantly higher in PD patients than in controls, suggesting that this polymorphism may have a role in the development of PD in these patients.
\end{abstract}

(c) 2013 Elsevier Ireland Ltd. All rights reserved.

\section{Introduction}

Parkinson's disease (PD) is one of the most common neurodegenerative disorders. The characteristic neuropathological features are the presence of Lewy bodies and the loss of dopaminergic cells in the substantia nigra pars compacta, but the precise pathomechanism is still not fully understood. The most common concepts are related to the genetic background and environmental effects [5]. Indeed, a number of genetic risk factors and gene-environment interactions have been implicated in the pathogenesis of PD $[13,14,19-21,24,25,29,37]$. Vitamin D, as an environmental factor, has been the subject of various studies on different neurological disorders, from which it has emerged that a vitamin D deficiency is associated with an increased risk of many diseases, including schizophrenia, autism, multiple sclerosis, Alzheimer's disease and PD $[1,3,4,7,9,22,26-28,30,33,35]$.

\footnotetext{
* Corresponding author. Tel.: +36 62 545348; fax: +36 62545597.

E-mail address: klivenyi.peter@med.u-szeged.hu (P. Klivenyi).
}

In humans, the majority of vitamin $\mathrm{D}$ is synthesized via the cleavage of a cholesterol metabolite in the epidermis by UVB, with further metabolism to the primary circulating form of vitamin $D$, 25-hydroxyvitamin D (25OHD), in the liver. This compound circulates in the blood in a form bound to vitamin $\mathrm{D}$ binding protein and in the kidneys 25OHD is metabolized by $1-\alpha$-hydroxylase to its active form, 1,25-dihydroxyvitamin $\mathrm{D}$ (1,25OHD). 1,25OHD binds to vitamin D receptors (VDRs) and influences calcium homeostasis, neurotrophic signaling, immunoregulation, cell growth and differentiation $[8,16,17]$. Both 1 - $\alpha$-hydroxylase and VDRs are expressed in numerous body tissues, including the brain [10].

The VDR gene encodes a nuclear transcription factor. The human gene is localized to $12 \mathrm{q} 12$ and various polymorphisms have been reported in it [38]. The level of vitamin $\mathrm{D}$ in $\mathrm{PD}$ has been analyzed in number of studies. A Japanese population exhibited a higher incidence of hip fractures and lower serum levels of 250HD in PD patients as compared with the healthy controls [34,35], observations that were confirmed in a Caucasian population [9]. The serum 250HD level correlated negatively with the severity of PD, measured in terms of the Hoehn \&Yahr stage and the Unified Parkinson's 
Table 1

Characteristics of PD patients and healthy controls.

\begin{tabular}{lll}
\hline & PD group (\%) & Control group (\%) \\
\hline No. & 100 & 109 \\
Age (mean \pm SEM) & $66.4 \pm 9.3$ & $64.0 \pm 8.2$ \\
Age at onset $\leq 60$ & $52(52)$ & \\
Age at onset $>60$ & $48(48)$ & \\
Gender & & $54(49.5)$ \\
Male & $44(44)$ & $55(50.5)$ \\
Female & $56(56)$ & \\
\hline
\end{tabular}

Disease Rating Scale (UPDRS) [34-36]. Whereas Sato et al. [34] reported a negative correlation between the $1,250 \mathrm{HD}$ level and the UPDRS score, Suzuki et al. [36] could not confirm this finding.

However, only limited data are available regarding the association between VDR polymorphisms and PD. Suzuki et al. [36] found that FokI CC genotype was associated with milder forms of PD in a Japanese population. Furthermore, an association between the BsmI bb genotype and PD was demonstrated in a Korean population [18]. A recent genome-wide association study revealed the association of VDR polymorphisms with the risk of PD and the age at onset in a Caucasian population [6]. In a Chinese study it was described that FokI $C$ allele associates with an increased risk of PD as well as early-onset PD [12].

The study we report here related to whether the known VDR gene polymorphisms ApaI, FokI, TaqI and BsmI are associated with $\mathrm{PD}$ in the Hungarian population, which belongs to the Caucasian race.

\section{Materials and methods}

\subsection{Subjects}

100 idiopathic PD patients (mean age: $66.4 \pm 9.3 \mathrm{yr} ; 44$ men and 56 women) were enrolled. The patients were evaluated by movement disorders specialists, who confirmed the diagnosis of idiopathic PD. Secondary forms of parkinsonism were excluded. The age at onset was determined from the medical records and the cases were categorized as early-onset (diagnosed $\leq 60 \mathrm{yr}$ ) or late-onset (diagnosed >60 yr) PD (Table 1). The Park2 and LRRK2 mutations were not present.

The control group comprised 109 healthy individuals (mean age: $64.0 \pm 8.2 \mathrm{yr} ; 54$ men and 55 women) who had no history of neurological or psychiatric disorders (Table 1 ). The patients and healthy controls, all of Hungarian origin, were selected from the Department of Neurology and Department of Medical Microbiology and Immunobiology at the University of Szeged. The study was approved by the Ethics Committee of the Faculty of Medicine, University of Szeged. All study participants gave their written informed consent, in accordance with the Declaration of Helsinki.

\subsection{DNA isolation}

Genomic DNA was isolated from the peripheral blood by a standard desalting method [23], and stored at $-20^{\circ} \mathrm{C}$ until further use.

The VDR polymorphisms were determined by polymerase chain reaction (PCR) techniques in a thermal cycler (Applied Biosystems 2720 Thermal Cycler, Applied Biosystems, Foster City, CA, USA) and restriction fragment-length polymorphism (RFLP).

\subsection{Genotyping}

For amplification of the FokI C/T polymorphism (rs10735810) the following primers were used [15]: forward primer 5'-AGC TGG
CCC TGG CAC TGA CTC TGC TCT-3' and reverse primer 5'-ATG GAA ACA CCT TGC TTC TTC TCC CTC-3'. The PCR amplification was carried out with the following cycling parameters: $95^{\circ} \mathrm{C}$ for $5 \mathrm{~min}$, and then 30 cycles of $95^{\circ} \mathrm{C}$ for $30 \mathrm{~s}, 60^{\circ} \mathrm{C}$ for $30 \mathrm{~s}$, and $72^{\circ} \mathrm{C}$ for $30 \mathrm{~s}$, and finally $72^{\circ} \mathrm{C}$ for $7 \mathrm{~min}$. The PCR products were digested with the FokI restriction enzyme (Fermentas, Vilnius, Lithuania) at $55^{\circ} \mathrm{C}$ for $3 \mathrm{~h}$. The digested products were separated by agarose gel electrophoresis. The genotypes were defined as CC (265 bp), TT (169 and 96 bp) or CT (265, 169 and $96 \mathrm{bp})$.

The BsmI A/G polymorphic site of intron 8 (rs1544410) was amplified with previously described primers [18]: forward primer 5'-CAA CCA AGA CTA CAA GTA CCG CGT CAG TGA-3' and reverse primer 5'-AAC CAG CGG GAA GAG GTC AAG GG-3'. The PCR conditions were as follows: $95^{\circ} \mathrm{C}$ for $10 \mathrm{~min}, 95^{\circ} \mathrm{C}$ for $30 \mathrm{~s}, 59^{\circ} \mathrm{C}$ for $30 \mathrm{~s}$ and $72^{\circ} \mathrm{C}$ for $50 \mathrm{~s}$ for 35 cycles, and finally $72^{\circ} \mathrm{C}$ for $10 \mathrm{~min}$. The $\mathrm{PCR}$ products were digested with the restriction enzyme Mva12691 (Fermentas, Vilnius, Lithuania) at $37^{\circ} \mathrm{C}$ overnight. Fragments were separated by electrophoresis in $2 \%$ stained agarose gels and visualized in UV light. The genotypes were defined as AA ( $825 \mathrm{bp}$ ), GG (650 and $175 \mathrm{bp}$ ) or $\mathrm{AG}(825,650$ and $175 \mathrm{bp})$.

PCR amplification of the polymorphic TaqI T/C site (rs731236) was performed with the following primers [31]: forward $5^{\prime}-\mathrm{CAG}$ AGC ATG GAC AGG GAG CAA-3' and reverse 5'-CAC TTC GAG CAC AAG GGG CGT TAG C-3'. The PCR conditions were identical to those for the BsmI polymorphism. The PCR products were digested with the TaqI restriction enzyme (Fermentas, Vilnius, Lithuania) at $65^{\circ} \mathrm{C}$ for $3 \mathrm{~h}$ and fragments were analyzed by electrophoresis in $2 \%$ agarose gel. The absence of the TaqI restriction site on both alleles (TT) led to the $501 \mathrm{bp}$ fragment, whereas the presence of the restriction site on both alleles (CC) yielded bands of 295 and $206 \mathrm{bp}$. The presence of the 501, 295 and 206 bp fragments reflected the TC heterozygotes.

The ApaI G/T polymorphic site (rs7976091) was amplified with previously described primers [32]: forward primer 5'-CAA CCA AGA CTA CAA GTA CCG CGT CAG TGA-3' and reverse primer 5'-CAC TTC GAG CAC AAG GGG CGT TAG C- $3^{\prime}$. The PCR conditions were: $95^{\circ} \mathrm{C}$ for $10 \mathrm{~min}$, followed by 35 cycles of $95^{\circ} \mathrm{C}$ for $30 \mathrm{~s}, 59^{\circ} \mathrm{C}$ for $30 \mathrm{~s}$ and $72{ }^{\circ} \mathrm{C}$ for $2 \mathrm{~min}$, and finally $72^{\circ} \mathrm{C}$ for $7 \mathrm{~min}$. The PCR products were incubated with the ApaI restriction enzyme (Fermentas, Vilnius, Lithuania) at $37^{\circ} \mathrm{C}$ overnight. The genotypes were defined as TT (absence of restriction site, one band at $2000 \mathrm{bp}$ ), TG (heterozygote, three bands at 2000, 1700 and $300 \mathrm{bp}$ ) and GG (presence of the restriction site, two bands at 1700 and $300 \mathrm{bp}$ ).

\subsection{Statistical analysis}

All statistical analyses were performed with the SPSS Statistics 17.0 software (SPSS Inc., Chicago, IL, USA). The difference in genotype frequencies was analyzed by using the Fisher's exact test or the $\chi^{2}$ test. The associations between the genotypes and the PD were estimated via the odds ratio (OR), with a $95 \%$ confidence interval $(\mathrm{CI})(95 \% \mathrm{CI})$. A $p$ value of less than 0.05 was considered statistically significant. The observed FokI, BsmI, ApaI and TaqI genotype frequencies were in accordance with the Hardy-Weinberg equilibrium in both the patients and the controls.

\section{Results}

\subsection{VDR FokI polymorphism}

The distributions of FokI restriction site genotypes in the PD patients and the controls are shown in Table 2. There was a significant difference in genotypes between the PD patients and the healthy controls $\left(\chi^{2}=6.7 ; p=0.035\right)$. The frequency of genotype 
Table 2

VDR FokI genotypes and allele frequencies in the PD patients and the controls.

\begin{tabular}{|c|c|c|c|c|c|c|c|}
\hline & \multicolumn{4}{|l|}{ Genotype } & \multicolumn{3}{|c|}{ Allele frequency } \\
\hline & CC (\%) & $\mathrm{CT}(\%)$ & TT (\%) & $p$ & $\mathrm{C}(\%)$ & $\mathrm{T}(\%)$ & $p$ \\
\hline PD patients & $42(42)$ & $48(48)$ & $10(10)$ & 0.035 & $132(66)$ & $68(34)$ & 0.017 \\
\hline Control & $35(32.1)$ & $49(45)$ & $25(22.9)$ & & $119(54.6)$ & $99(45.4)$ & \\
\hline
\end{tabular}

Table 3

Relationship between age at onset and gender in the PD patients as a function of the VDR FokI genotyping.

\begin{tabular}{lllll}
\hline & $\mathrm{CC}(\%)$ & $\mathrm{CT}(\%)$ & $\mathrm{TT}(\%)$ & $p$ \\
\hline $\begin{array}{l}\text { Age at onset } \\
\leq 60 \mathrm{yr}\end{array}$ & $22(42.3)$ & $24(46.2)$ & $6(11.5)$ & 0.841 \\
$>60 \mathrm{yr}$ & $20(41.7)$ & $24(50)$ & $4(8.3)$ & \\
$\begin{array}{l}\text { Gender } \\
\text { Male }\end{array}$ & $18(40.9)$ & $22(50)$ & $4(9.1)$ & 0.958 \\
Female & $24(42.9)$ & $26(46.4)$ & $6(10.7)$ & \\
\hline
\end{tabular}

with $\mathrm{C}(\mathrm{CC}+\mathrm{CT})$ was significantly higher among the patients with PD relative to the controls: $\mathrm{OR}=2.677$ and $95 \% \mathrm{CI}=1.214-5.91$, $p=0.015$ for CC + CT vs. TT. Moreover, the $\mathrm{C}$ allele showed a significant association with PD group ( $\mathrm{OR}=1.615,95 \% \mathrm{CI}=1.087-2.399$, $p=0.017$ ). There was no difference between the FokI polymorphism and gender in PD group, and no significant association was found between this polymorphism and the age at onset (Table 3 ).

\subsection{VDR BsmI polymorphism}

There was no significant difference in the BsmI genotypic distribution $(\mathrm{OR}=0.890,95 \% \mathrm{CI}=0.478-1.654, p=0.753$ for $\mathrm{GG}$ vs $\mathrm{AA}+\mathrm{AG})$ and allele frequency $(\mathrm{OR}=0.977,95 \% \mathrm{CI}=0.665-1.434$, $p=0.905$ ) between the PD patients and the healthy controls. The BsmI genotypic distribution, the allele frequency, the male to female ratio and the age at onset of the PD patients are presented in Table 4.

\subsection{VDR TaqI polymorphism}

The frequencies of the TaqI genotype in the PD group and the controls were similar ( $\mathrm{OR}=0.840,95 \% \mathrm{CI}=0.399-1.767, p=0.646$ for TT + TC vs. CC) and we did not find differences in allele distribution ( $\mathrm{OR}=0.802,95 \% \mathrm{CI}=0.540-1.190, p=0.273$ ). There was no significant difference in the male to female ratio and the age at onset in the various TaqI polymorphism subgroups (Table 5).

\subsection{VDR ApaI polymorphism}

The Apal genotype frequencies $(\mathrm{OR}=1.352, \quad 95 \%$ $\mathrm{CI}=0.654-2.796, p=0.466$ for GG vs. TT $+\mathrm{TG}$ ) and the allele distribution $(\mathrm{OR}=1.177,95 \% \mathrm{CI}=0.793-1.748, p=0.417)$ were similar in the healthy controls and the patients with PD (Table 6). There was no statistically significant association between the ApaI polymorphism and the age at onset in PD patients, and no significant difference was found between this polymorphism and gender in the PD group.

\section{Discussion}

This work involved a study of VDR polymorphism in PD patients among Hungarians. Earlier reports revealed that 250HD levels were decreased in PD patients in Japanese and Caucasian populations $[9,34,35]$ and demonstrated a higher incidence of osteoporosis in PD patients of both genders, with a decreased bone mass index and a reduced bone mineral density [11,34]. Overall, it has been clearly shown that the vitamin D metabolism is affected in PD patients.

Table 4

VDR BsmI genotypes and allele distributions in patients with PD and controls.

\begin{tabular}{|c|c|c|c|c|c|c|c|}
\hline & \multicolumn{4}{|l|}{ Genotype } & \multicolumn{3}{|c|}{ Allele frequency } \\
\hline & $\mathrm{AA}(\%)$ & AG (\%) & GG (\%) & $p$ & $A(\%)$ & $G(\%)$ & $p$ \\
\hline PD patients & $24(24)$ & $49(49)$ & $27(27)$ & 0.902 & $97(48.5)$ & $103(51.5)$ & 0.905 \\
\hline Controls & $25(22.9)$ & $57(52.3)$ & $27(24.8)$ & & $107(49)$ & $111(51)$ & \\
\hline \multicolumn{8}{|l|}{ Age at onset } \\
\hline$\leq 60 \mathrm{yr}$ & $9(17.3)$ & 27 (51.9) & $16(30.8)$ & 0.261 & & & \\
\hline$>60 \mathrm{yr}$ & $15(31.3)$ & $22(45.8)$ & $11(22.9)$ & & & & \\
\hline \multicolumn{8}{|l|}{ Gender } \\
\hline Male & $7(15.9)$ & $22(50)$ & $15(34.1)$ & 0.161 & & & \\
\hline Female & $17(30.4)$ & $27(48.2)$ & $12(21.4)$ & & & & \\
\hline
\end{tabular}

Table 5

VDR TaqI genotypes and allele frequencies in patients with PD and controls.

\begin{tabular}{|c|c|c|c|c|c|c|c|}
\hline & \multicolumn{4}{|l|}{ Genotype } & \multicolumn{3}{|c|}{ Allele frequency } \\
\hline & $\mathrm{TT}(\%)$ & TC $(\%)$ & $\mathrm{CC}(\%)$ & $p$ & $\mathrm{~T}(\%)$ & $C(\%)$ & $p$ \\
\hline PD patients & $35(35)$ & $48(48)$ & $17(17)$ & 0.485 & $118(59)$ & $82(41)$ & 0.273 \\
\hline Controls & $47(43.1)$ & $46(42.2)$ & $16(14.7)$ & & $140(64.2)$ & $78(35.8)$ & \\
\hline \multicolumn{8}{|l|}{ Age at onset } \\
\hline$\leq 60 \mathrm{yr}$ & $22(42.3)$ & $23(44.2)$ & $7(13.5)$ & 0.265 & & & \\
\hline$>60 \mathrm{yr}$ & $13(27.1)$ & $25(52.1)$ & $10(20.8)$ & & & & \\
\hline \multicolumn{8}{|l|}{ Gender } \\
\hline Male & $18(40.9)$ & $20(45.5)$ & $6(13.6)$ & 0.528 & & & \\
\hline Female & $17(30.4)$ & $28(50)$ & $11(19.6)$ & & & & \\
\hline
\end{tabular}


Table 6

VDR ApaI genotypes and allele frequencies in the PD patients and the controls.

\begin{tabular}{|c|c|c|c|c|c|c|c|}
\hline & \multicolumn{4}{|l|}{ Genotype } & \multicolumn{3}{|c|}{ Allele frequency } \\
\hline & TT (\%) & TG (\%) & GG (\%) & $p$ & $\mathrm{~T}(\%)$ & $\mathrm{G}(\%)$ & $p$ \\
\hline PD patients & $42(42)$ & $43(43)$ & $15(15)$ & 0.691 & 127 (63.5) & $73(36.5)$ & 0.417 \\
\hline Controls & $42(38.5)$ & $46(42.2)$ & $21(19.3)$ & & $130(59.6)$ & $88(40.4)$ & \\
\hline \multicolumn{8}{|l|}{ Age at onset } \\
\hline$\leq 60 \mathrm{yr}$ & $18(34.6)$ & $23(44.2)$ & $11(21.2)$ & 0.130 & & & \\
\hline$>60 \mathrm{yr}$ & $24(50)$ & $20(41.7)$ & $4(8.3)$ & & & & \\
\hline \multicolumn{8}{|l|}{ Gender } \\
\hline Male & $13(29.5)$ & $22(50)$ & $9(20.5)$ & 0.07 & & & \\
\hline Female & $29(51.8)$ & $21(37.5)$ & $6(10.7)$ & & & & \\
\hline
\end{tabular}

Differences have also been demonstrated in the VDR polymorphisms in PD in Japanese, Korean, Chinese and Caucasian populations $[6,12,18,36]$.

Our results have indicated a significant difference in the FokI genotype distribution between PD and controls in Hungarian population; the frequency of the $C$ allele was significantly higher in PD patients than in the healthy control group, suggesting that the $C$ allele may have a role in the development of PD.

Previously, a Japanese and a Chinese study detected difference in this polymorphism between healthy subjects and PD patients. In Japan, FokI CC genotype was associated with milder forms of PD [36]. Han et al. [12] suggested that FokI C allele might be a risk factor for sporadic PD development.

FokI polymorphism is located in exon 2 at the $5^{\prime}$ coding region of the gene. This polymorphism results in different translation initiation sites: if the VDR gene contains $C$ allele, the protein will be three amino acids shorter. Difference in length may result in altered VDR function $[2,38]$.

BsmI, ApaI and TaqI polymorphisms are located in the $3^{\prime}-$ end region of the VDR gene, which do not result in changes in the amino acid sequence of the VDR [38]. We did not identify significant associations with these VDR polymorphisms. A Korean study detected difference in the genotype frequency of BsmI polymorphism between healthy subjects and PD patients; the bb genotype in that study was more common in Korean PD patients than in controls [18]. No difference in BsmI polymorphism was identified in Japanese patients [36], where the FokI CC genotype displayed a strong association with the milder forms of PD.

Our data demonstrated no significant associations between VDR ApaI polymorphism and PD, whereas the Apal polymorphism was associated with the early-onset form of PD in American Caucasians. Interestingly, there was no association between FokI polymorphism and PD patients among American Caucasians, reflecting differences in ethnicity among Caucasians [6].

These diverse data suggest that the Caucasian population is not homogeneous in this respect. We did not detect an association between the age at onset, the male-female ratio and the VDR polymorphisms in the PD group. The differences between the results of the various authors must be interpreted with regard to the facts that the study populations and sample sizes differed, with the additional possibility of certain ethnic variations.

As far as we are aware, this is the first report on the potential correlation between a VDR polymorphism and PD from a European country. We conclude overall that the $C$ allele of the VDR FokI polymorphism may be associated with PD in a Caucasian population.

\section{Conflict of interest}

None declared.

\section{Author contributions}

Conceived and designed the experiments: RT, PK. Performed the experiments: RT, NT. Collected the samples: NT, FS, ZSZ, PK. Analyzed the data: LSZ, RT. Wrote the paper: RT, LSZ, IP, PK. Study supervision or coordination: LV, PK.

\section{Acknowledgements}

This work was supported by grants ETT 026-04 and "TÁMOP4.2.1/B-09/1/KONV-2010-0005 - Creating the Centre of Excellence at the University of Szeged", which is promoted by the European Union and co-financed by the European Regional Development Fund. This research was supported by the European Union and the State of Hungary, co-financed by the European Social Fund in the framework of TÁMOP 4.2.4.A/2-11-1-2012-0001 National Excellence Program.

\section{References}

[1] L. Amezcua, R.H. Chung, D.V. Conti, A.M. Langer-Gould, Vitamin D levels in Hispanics with multiple sclerosis, Journal of Neurology 259 (2012) 2565-2570.

[2] H. Arai, K. Miyamoto, Y. Taketani, H. Yamamoto, Y. Iemori, K. Morita, T. Tonai, T. Nishisho, S. Mori, E. Takeda, A vitamin D receptor gene polymorphism in the translation initiation codon: effect on protein activity and relation to bone mineral density in Japanese women, Journal of Bone and Mineral Research 12 (1997) 915-921.

[3] A. Ascherio, K.L. Munger, K.C. Simon, Vitamin D and multiple sclerosis, The Lancet Neurology 9 (2010) 599-612.

[4] J.S. Buell, B. Dawson-Hughes, T.M. Scott, D.E. Weiner, G.E. Dallal, W.Q. Qui, P. Bergethon, I.H. Rosenberg, M.F. Folstein, S. Patz, R.A. Bhadelia, K.L. Tucker, 25-Hydroxyvitamin D, dementia, and cerebrovascular pathology in elders receiving home services, Neurology 74 (2010) 18-26.

[5] L.F. Burbulla, R. Kruger, Converging environmental and genetic pathways in the pathogenesis of Parkinson's disease, Journal of the Neurological Sciences 306 (2011) 1-8.

[6] M.W. Butler, A. Burt, T.L. Edwards, S. Zuchner, W.K. Scott, E.R. Martin, J.M. Vance, L. Wang, Vitamin D receptor gene as a candidate gene for Parkinson disease, Annals of Human Genetics 75 (2011) 201-210.

[7] J.J. Cannell, Autism and vitamin D, Medical Hypotheses 70 (2008) 750-759

[8] A.S. Dusso, A.J. Brown, E. Slatopolsky, Vitamin D, American Journal of Physiology. Renal Physiology 289 (2005) F8-F28.

[9] M.L. Evatt, M.R. Delong, N. Khazai, A. Rosen, S. Triche, V. Tangpricha, Prevalence of vitamin d insufficiency in patients with Parkinson disease and Alzheimer disease, Archives of Neurology 65 (2008) 1348-1352.

[10] D.W. Eyles, S. Smith, R. Kinobe, M. Hewison, J.J. McGrath, Distribution of the vitamin D receptor and 1 alpha-hydroxylase in human brain, Journal of Chemical Neuroanatomy 29 (2005) 21-30.

[11] H.A. Fink, M.A. Kuskowski, E.S. Orwoll, J.A. Cauley, K.E. Ensrud, Association between Parkinson's disease and low bone density and falls in older men: the osteoporotic fractures in men study, Journal of the American Geriatrics Society 53 (2005) 1559-1564.

[12] X. Han, L. Xue, Y. Li, B. Chen, A. Xie, Vitamin D receptor gene polymorphism and its association with Parkinson's disease in Chinese Han population, Neuroscience Letters 525 (2012) 29-33.

[13] D.B. Hancock, E.R. Martin, K. Fujiwara, M.A. Stacy, B.L. Scott, J.M. Stajich, R Jewett, Y.J. Li, M.A. Hauser, J.M. Vance, W.K. Scott, NOS2A and the modulating effect of cigarette smoking in Parkinson's disease, Annals of Neurology 60 (2006) 366-373. 
[14] D.B. Hancock, E.R. Martin, J.M. Vance, W.K. Scott, Nitric oxide synthase genes and their interactions with environmental factors in Parkinson's disease, Neurogenetics 9 (2008) 249-262.

[15] S.S. Harris, T.R. Eccleshall, C. Gross, B. Dawson-Hughes, D. Feldman, The vitamin D receptor start codon polymorphism (FokI) and bone mineral density in premenopausal American black and white women, Journal of Bone and Mineral Research 12 (1997) 1043-1048.

[16] S. Kato, The function of vitamin D receptor in vitamin D action, Journal of Biochemistry 127 (2000) 717-722.

[17] J.P. Kesby, D.W. Eyles, T.H. Burne, J.J. McGrath, The effects of vitamin D on brain development and adult brain function, Molecular and Cellular Endocrinology 347 (2011) 121-127.

[18] J.S. Kim, Y.I. Kim, C. Song, I. Yoon, J.W. Park, Y.B. Choi, H.T. Kim, K.S. Lee, Association of vitamin D receptor gene polymorphism and Parkinson's disease in Koreans, Journal of Korean Medical Science 20 (2005) 495-498.

[19] Y.J. Li, S.A. Oliveira, P. Xu, E.R. Martin, J.E. Stenger, C.R. Scherzer, M.A. Hauser, W.K. Scott, G.W. Small, M.A. Nance, R.L. Watts, J.P. Hubble, W.C. Koller, R. Pahwa, M.B.Stern, B.C. Hiner, J. Jankovic, C.G. Goetz, F. Mastaglia, L.T. Middleton, A.D. Roses, A.M. Saunders, D.E. Schmechel, S.R. Gullans, J.L. Haines, J.R. Gilbert, J.M. Vance, M.A. Pericak-Vance, C. Hulette, K.A. Welsh-Bohmer, Glutathione Stransferase omega-1 modifies age-at-onset of Alzheimer disease and Parkinson disease, Human Molecular Genetics 12 (2003) 3259-3267.

[20] D.M. Maraganore, M. de Andrade, A. Elbaz, M.J. Farrer, J.P. Ioannidis, R. Kruger, W.A. Rocca, N.K. Schneider, T.G. Lesnick, S.J. Lincoln, M.M. Hulihan, J.O. Aasly, T. Ashizawa, M.C. Chartier-Harlin, H. Checkoway, C. Ferrarese, G. Hadjigeorgiou, N. Hattori, H. Kawakami, J.C. Lambert, T. Lynch, G.D. Mellick, S. Papapetropoulos, A. Parsian, A. Quattrone, O. Riess, E.K. Tan, C. Van Broeckhoven, Collaborative analysis of alpha-synuclein gene promoter variability and Parkinson disease, JAMA 296 (2006) 661-670.

[21] C.C. McCulloch, D.M. Kay, S.A. Factor, A. Samii, J.G. Nutt, D.S. Higgins, A. Griffith, J.W. Roberts, B.C. Leis, J.S. Montimurro, C.P. Zabetian, H. Payami, Exploring geneenvironment interactions in Parkinson's disease, Human Genetics 123 (2008) $257-265$.

[22] J. McGrath, Hypothesis: is low prenatal vitamin D a risk-modifying factor for schizophrenia? Schizophrenia Research 40 (1999) 173-177.

[23] S.A. Miller, D.D. Dykes, H.F. Polesky, A simple salting out procedure for extracting DNA from human nucleated cells, Nucleic Acids Research 16 (1988) 1215.

[24] I. Mizuta, W. Satake, Y. Nakabayashi, C. Ito, S. Suzuki, Y. Momose, Y. Nagai, A. Oka, H. Inoko, J. Fukae, Y. Saito, M. Sawabe, S. Murayama, M. Yamamoto, N. Hattori, M. Murata, T. Toda, Multiple candidate gene analysis identifies alphasynuclein as a susceptibility gene for sporadic Parkinson's disease, Human Molecular Genetics 15 (2006) 1151-1158.

[25] I. Mizuta, T. Tsunoda, W. Satake, Y. Nakabayashi, M. Watanabe, A. Takeda, K. Hasegawa, K. Nakashima, M. Yamamoto, N. Hattori, M. Murata, T. Toda,
Calbindin 1, fibroblast growth factor 20, and alpha-synuclein in sporadic Parkinson's disease, Human Genetics 124 (2008) 89-94.

[26] E.M. Mowry, Vitamin D: evidence for its role as a prognostic factor in multiple sclerosis, Journal of the Neurological Sciences 311 (2011) 19-22.

[27] K.L. Munger, L.I. Levin, B.W. Hollis, N.S. Howard, A. Ascherio, Serum 25hydroxyvitamin D levels and risk of multiple sclerosis, JAMA 296 (2006) 2832-2838

[28] H.L. Newmark, J. Newmark, Vitamin D and Parkinson's disease - a hypothesis, Movement Disorders 22 (2007) 461-468.

[29] S.A. Oliveira, Y.J. Li, M.A. Noureddine, S. Zuchner, X. Qin, M.A. Pericak-Vance, J.M. Vance, Identification of risk and age-at-onset genes on chromosome $1 \mathrm{p}$ in Parkinson disease, American Journal of Human Genetics 77 (2005) $252-264$.

[30] S.M. Orton, S.V. Ramagopalan, A.E. Para, M.R. Lincoln, L. Handunnetthi, M.J. Chao, J. Morahan, K.M. Morrison, A.D. Sadovnick, G.C. Ebers, Vitamin D metabolic pathway genes and risk of multiple sclerosis in Canadians, Journal of the Neurological Sciences 305 (2011) 116-120.

[31] B.L. Riggs, T.V. Nguyen, L.J. Melton 3rd, N.A. Morrison, W.M. O‘Fallon, P.J. Kelly, K.S. Egan, P.N. Sambrook, J.M. Muhs, J.A. Eisman, The contribution of vitamin $\mathrm{D}$ receptor gene alleles to the determination of bone mineral density in normal and osteoporotic women, Journal of Bone and Mineral Research 10 (1995) 991-996.

[32] J. Sainz, J.M. Van Tornout, M.L. Loro, J. Sayre, T.F. Roe, V. Gilsanz, Vitamin Dreceptor gene polymorphisms and bone density in prepubertal American girls of Mexican descent, New England Journal of Medicine 337 (1997) 77-82.

[33] Y. Sato, T. Asoh, K. Oizumi, High prevalence of vitamin D deficiency and reduced bone mass in elderly women with Alzheimer's disease, Bone 23 (1998) $555-557$.

[34] Y. Sato, Y. Honda, J. Iwamoto, T. Kanoko, K. Satoh, Abnormal bone and calcium metabolism in immobilized Parkinson's disease patients, Movement Disorders 20 (2005) 1598-1603.

[35] Y. Sato, M. Kikuyama, K. Oizumi, High prevalence of vitamin D deficiency and reduced bone mass in Parkinson's disease, Neurology 49 (1997) 1273-1278.

[36] M. Suzuki, M. Yoshioka, M. Hashimoto, M. Murakami, K. Kawasaki, M. Noya D. Takahashi, M. Urashima, 25-Hydroxyvitamin D, vitamin D receptor gene polymorphisms, and severity of Parkinson's disease, Movement Disorders 27 (2012) 264-271

[37] J.M. van der Walt, M.A. Noureddine, R. Kittappa, M.A. Hauser, W.K. Scott, R. McKay, F. Zhang, J.M. Stajich, K. Fujiwara, B.L. Scott, M.A. Pericak-Vance, J.M. Vance, E.R. Martin, Fibroblast growth factor 20 polymorphisms and haplotypes strongly influence risk of Parkinson disease, American Journal of Human Genetics 74 (2004) 1121-1127.

[38] J.M. Zmuda, J.A. Cauley, R.E. Ferrell, Molecular epidemiology of vitamin D receptor gene variants, Epidemiologic Reviews 22 (2000) 203-217. 
II. 
Research paper

\title{
An assessment of the frequency of mutations in the GBA and VPS35 genes in Hungarian patients with sporadic Parkinson's disease
}

\author{
Rita Török ${ }^{a}$, Dénes Zádori ${ }^{a}$, Nóra Török ${ }^{a}$, Éva Csility ${ }^{a}$, László Vécsei ${ }^{a, b}$, Péter Klivényi ${ }^{a, *}$ \\ a Department of Neurology, University of Szeged, H-6725 Szeged, Semmelweis u. 6, Hungary \\ ${ }^{\mathrm{b}}$ MTA-SZTE Neuroscience Research Group, H-6725 Szeged, Semmelweis u. 6, Hungary
}

\section{H I G H L I G H T S}

- Mutations of GBA and the VPS35 gene have been investigated in a Hungarian PD population.

- Heterozygous mutation (L444P) of GBA was found in $2.4 \%$ of the PD cases ( $0 \%$ in the controls).

- All the PD patients who carried the mutations were in the EOPD group.

- No association was detected between the D620N mutation of the VPS35 gene and PD.

\section{A R T I C L E I N F O}

\section{Article history:}

Received 4 August 2015

Received in revised form 29 October 2015

Accepted 1 November 2015

Available online 4 November 2015

\section{Keywords:}

Parkinson's disease

GBA mutations

L444P

VPS35 mutation

\begin{abstract}
A B S T R A C T
Parkinson's disease (PD) is the second most common neurodegenerative disorder, with cases of either familial or sporadic origin. Several polymorphisms in a number of genes have been proved to have an important role in the development of PD. Particular attention has recently been paid to genes of the glucocerebrosidase (GBA) and the vacuolar protein sorting-associated protein 35 (VPS35).

In this study, the three most common mutations (L444P, N370S and R120W) of the GBA gene and the D620N mutation of the VPS35 gene were examined in 124 Hungarian patients diagnosed with sporadic PD (SPD) and 122 control subjects.

The frequency of the L444P mutation of the GBA gene proved to be higher in the PD patients (2.4\%) than in the controls ( $0 \%)$, although the difference was not statistically significant. All the patients who carried the mutant allele were in the early-onset PD (EOPD) group. However, neither the R120W nor the N370S variant of the GBA gene nor D620N mutation of the VPS35 gene were detected among the PD cases or the controls.

Even though these results suggest that the studied mutations are quite rare in SPD patients, the most frequent L444P mutation of the GBA gene may be associated with the development of EOPD in the Hungarian population.
\end{abstract}

(c) 2015 Elsevier Ireland Ltd. All rights reserved.

\section{Introduction}

The most prominent neuropathological features of Parkinson's disease (PD), the second most common neurodegenerative disorder, are the loss of dopaminergic neurons in the substantia nigra pars compacta and the presence of Lewy bodies, although the precise pathomechanism is still not fully understood. Gene-environment interactions are certainly implicated in the multifactorial pathogenesis of PD [6].

\footnotetext{
* Corresponding author. Fax: +36 62545597.

E-mail address: klivenyi.peter@med.u-szeged.hu (P. Klivényi).
}

The majority of PD cases are sporadic; only $15-20 \%$ of the cases are identified as familial. In the background of these familial cases, numerous mutations have been identified in several genes that cause autosomal dominant (PARK1, PARK3, PARK4, PARK5, PARK8 and PARK11) or autosomal recessive (PARK2, PARK6, PARK7, PARK9, PARK14 and PARK15) forms of PD [9]. The D620N mutation in the vacuolar protein sorting-associated protein 35 (VPS35) was recently discovered as a new cause of PD [12]. Furthermore, genetic risk factors have been identified in sporadic forms of PD (SPD) [9]. The gene coding for glucocerebrosidase (GBA) has been reported to have a potential role in the development of PD [5].

Gaucher's disease (GD) is an autosomal recessively inherited glycolipid storage disorder caused by a deficiency of the lysosomal 
enzyme GBA. Several studies have reported a clinical, neuropathological or genetic association between GD and PD $[5,8,20]$.

The GBA gene is localized at chromosome 1q21 and has more than 300 mutations [16]. Numerous genotyping studies have demonstrated associations between several GBA mutations and $P D$ in different ethnic groups. As an example, the frequencies of GBA mutations in PD patients were highest amongst Ashkenazi Jews (ranging from $13.7 \%$ to $31.3 \%$ ) $[1,7,13]$. Furthermore, several studies have indicated that a high frequency of GBA mutations is related to an increased risk of PD amongst Japanese, Canadian, Portuguese, Greek, Norwegian, Italian, Serbian and Chinese populations $[4,11,18,25,26,28,35,38,41]$.

N370S has been demonstrated to be the most common mutation among Ashkenazi Jewish PD patients (14.1\%), and it is also the most frequent mutation in several European (e.g. Serbian (1.9\%), French (2.9\%) and Portuguese (2.2\%)) populations [4,18,20,32]. A Japanese study detected a significant association between the R120W mutation and PD [25]. L444P is the most common variant among non-Ashkenazi Jewish patients. The possible association between this mutation and PD has been investigated in a number of studies $[23,38,39,41]$.

The VPS35 gene, which is involved in the development of many neurodegenerative diseases, including Alzheimer's disease and PD $[12,33]$, is localized to $16 q 11.2$, and various mutations have been reported in it [40]. The VPS35 protein is a key component of the retromer complex which mediates the retrograde transport of proteins from endosomes to the trans-Golgi network [3]. Amongst the mutations of the VPS35 gene, the D620N missense mutation has been reported to be pathogenic for PD [37,42], mainly in the autosomal dominantly inherited cases, but it has additionally been detected in some sporadic PD cases $[2,19,21,31,37,42]$. A recent multicentre study determined the frequencies of VPS35 mutations in PD in various populations. The D620N mutation was found in 5 familial and 2 sporadic cases [30]. In contrast, other studies suggest that there is no such mutation in SPD in the Caucasian population [19,31].

No study has been conducted previously to assess the frequency of GBA or VPS35 gene mutations in Hungarian PD patients. The aim of the current preliminary study was therefore to investigate whether any of the L444P, N370S and R120W mutations of the GBA gene or the D620N mutation of the VPS35 gene is present in SPD in the Hungarian population, which belongs in the Caucasian race.

\section{Material and methods}

\subsection{Subjects}

124 SPD patients (mean age: $66.5 \pm 9.5$ years) were enrolled in the study. The mean age at onset of PD was $59.1 \pm 10.9$ years. Early-onset PD (EOPD) was defined as an age at onset $\leq 60$ years ( 67 subjects) and late-onset PD (LOPD) as an age at onset $>60$ years ( 57 subjects). All of the patients were examined by movement disorder specialists, who confirmed the diagnosis of SPD. Secondary forms of parkinsonism were excluded. The PARK2 and PARK8 mutations were not present in the assessed patient population.

The control group comprised 122 volunteer individuals (mean age: $64.3 \pm 8.2$ years) who had no history of neurological or psychiatric disorders (Table 1 ). All the patients with SPD and all the controls were of Hungarian origin and were enrolled in the Department of Neurology at the University of Szeged.

The study protocol was approved by the Medical Research Council Scientific and Research Ethics Committee (47066-3/2013/EKU (556/2013)) and all study participants gave their written informed consent in accordance with the Helsinki Declaration.
Table 1

Characteristics of groups of PD patients and controls.

\begin{tabular}{lll}
\hline & PD group & Control group \\
\hline No. & 124 & 122 \\
Age (years, mean \pm SD) & $66.5 \pm 9.5$ & $64.3 \pm 8.2$ \\
Age at onset $\leq 60$ years & $67(54 \%)$ & \\
Age at onset $>60$ years & $57(46 \%)$ & \\
\hline
\end{tabular}

\subsection{DNA isolation}

Genomic DNA was extracted from peripheral blood by a standard desalting method [24], and stored at $-20^{\circ} \mathrm{C}$ until further use.

\subsection{Analysis of GBA mutations}

The L444P, R120W and N370S polymorphisms of the GBA gene were determined in all the patients and the controls by using the polymerase chain reaction and restriction fragment-length polymorphism (PCR-RFLP) techniques. Three previously described primer pairs were used separately to amplify the DNA region of each mutation $[1,39]$. The PCR primers, annealing temperatures, restriction enzymes and fragment lengths are listed in Table 2 . The digested products were separated by agarose gel electrophoresis.

\subsection{Detection of VPS35 mutation}

The D620N mutation in the VPS35 gene was determined by PCRRFLP. The PCR conditions and primers were as described previously [34]. The PCR products were digested with the HinFI restriction enzyme (Thermo Scientific, Waltham, MA, USA) at $37^{\circ} \mathrm{C}$ for $30 \mathrm{~min}$. The digested products were separated by agarose gel electrophoresis. The genotypes were defined as GG $(257 \mathrm{bp}, 231 \mathrm{bp}, 139 \mathrm{bp}$, 74 bp, 18 bp), GA (257 bp, 231 bp, 213 bp, 139 bp, 74 bp, 18 bp) or AA (257 bp, 231 bp, 213 bp, 18 bp).

\subsection{Statistical analysis}

SPSS software version 22.0 was applied for the evaluation of the data populations. The genotype frequencies in the patients and the controls were analysed by using the Fisher exact test. The normality of the data was checked with the Kolmogorov-Smirnov test. Since the data exhibited Gaussian distribution, and the Levene test did not reveal significant differences in the homogeneity of variances, we applied the independent $t$ test for the comparison of the difference in age between the PD groups and the controls. Odds ratio (OR) and $95 \%$ confidence intervals $(95 \% \mathrm{CI})$ were calculated to test for an association between the GBA mutation and PD. A $p$ value of less than 0.05 was considered statistically significant.

\section{Results}

\subsection{GBA gene mutations}

Amongst the PD patients, 3 individuals (2.4\%) carried a heterozygous mutant GBA allele: in all 3 cases the L444P substitution. In contrast, no mutations were detected in the control group. The difference in mutation frequencies between the patients $(2.4 \%)$ and controls $(0 \%)$ was not statistically significant $(p=0.247)$. However, the carriers of the GBA mutation were at an increased risk of developing PD (OR=6.05, 95\% CI 0.300-122.06). Moreover, all the patients who carried the mutant allele were in the EOPD group. The frequency was significantly higher in the EOPD group than in the controls $(p=0.042)$. However, a comparison of the frequency between the EOPD group and the LOPD group failed to reveal any difference $(p=0.247)$. 
Table 2

Primers, PCR conditions and restriction enzymes used for the detection of GBA mutations.

\begin{tabular}{|c|c|c|c|c|c|c|}
\hline Mutation & Primer sequence & Annealing temperature $\left({ }^{\circ} \mathrm{C}\right)$ & Restriction enzyme & PCR (bp) & Wild type (bp) & Mutant (bp) \\
\hline L444P & $\begin{array}{l}\text { F:5'-GGAGGACCCAATTGGGTGCGT-3' } \\
\text { R: 5'-ACGCTGTCTTCAGCCCACTTC-3' }\end{array}$ & 59 & Ncil & 637 & 637 & 535,102 \\
\hline R120W & $\begin{array}{l}\text { F:5'-GCAGAGTCCCATACTCTCCT-3' } \\
\text { R:5'-TGGGTGACAGAGAGAGAGACT-3' }\end{array}$ & 56 & Ncil & 836 & $454,300,82$ & 536,300 \\
\hline N370S & $\begin{array}{l}\text { F: 5'-GCCTTTGTCCTTACCCTC } † \text { G-3' } \\
\text { R: 5'-GACAAAGTTACGCACCCAA-3' }\end{array}$ & 53 & Xhol & 105 & 105 & 89,16 \\
\hline
\end{tabular}

$\dagger$ A mismatch was introduced in the primer at one nucleotide to create a restriction site.

Neither the R120W nor the N370S variant of the GBA gene was identified among the assessed PD cases and controls.

\subsection{VPS35 gene mutation}

The common VPS35 D620N mutation was not detected either in the PD patients or in the controls in the assessed population.

\section{Discussion}

PD is a heterogeneous disorder. The majority of PD cases (75-80\%) are sporadic; the remaining $15-20 \%$ of the patients have a familial history. Sporadic PD may result from complex interactions between genomic and environmental factors. Genome-wide association studies (GWAS) are carried out to identify rare genetic variants that increase the risk of PD. Multiple GWAS on PD patients and controls have revealed numerous loci, including GBA and MAPT, as risk factors for sporadic PD [36].

Moreover, several genes (PARK1-18) have been identified that can cause autosomal dominant or autosomal recessive forms of PD [17]. They include some genes which play an important role in the pathogenesis of SPD [10,22]. The D620N mutation in VPS35 (PARK17) was recently discovered as a new cause of PD, mainly in the autosomal dominantly inherited cases, although it may additionally have a role in SPD, but the results are inconsistent [37,42].

In the present study, we examined the three common mutations (L444P, N370S and R120W) of the GBA gene and the D620N mutation of the VPS35 gene in the Hungarian population (124 patients with SPD and 122 controls).

Several studies have reported that the frequencies of GBA mutations are higher in PD patients (5-10\%) than in controls, but the range varies in different ethnic groups [29]. Our results indicated that the PD patients demonstrated a higher frequency (2.4\%) of the L444P mutation of the GBA gene as compared with the controls $(0 \%)$, although the difference was not significant. This finding is similar to those of previous studies that have reported associations between the L444P mutation and PD [23,38,39]. The L444P mutation was shown to occur with incidences of $2 \%, 1.39 \%$ and $1.14 \%$ amongst American non-Jewish, Canadian and British PD patients, respectively $[8,27,28]$. Moreover, an Eastern Canadian study concluded that the frequency of L444P was higher among PD patients (3.1\%) than among controls [15].

A number of studies have found that GBA mutations may be considered a risk factor, mainly in EOPD cases [8,14,39]. Our study revealed that all the patients who carried the mutant allele were in the EOPD group. These data emphasized the significance of the GBA mutation, particularly in EOPD cases.

Besides the L444P mutation, the other two most frequent mutations in non-Ashkenazi Jewish patients are N370S and R120W [32], and we therefore investigated these two GBA mutations too. We did not detect either the R120W or the N370S variant of the GBA gene among the PD cases or the controls, although the N370S mutation was earlier demonstrated in some European PD patients [18,26,32]. These diverse data suggest that the Caucasian population is not homogeneous in this respect.
Mutations in the VPS35 gene have been identified as a causative factor of the development of PD. The mutation carriers have been estimated to account for less than $1 \%$ of the PD population [19]. These mutations have been examined in a number of Caucasian populations, with different results $[19,30,31,37]$. We therefore investigated the presence of the D620N mutation of the VPS35 gene in SPD patients, but we were unable to identify this mutation in any of the patients or controls. This suggests that the D620N mutation of the VPS35 gene is at best a rare cause of SPD.

The differences between the results of the various studies might stem from the different sample size and the different study populations with the possibility of certain ethnic variations.

The genetic causes and risk factors of PD may serve as important tools through which to attain a better understanding of the pathomechanism. Since a genetic background is presumed in the development of SPD in some cases, it is important to investigate the different genetic factors in the various SPD populations, which may permit the development of new therapeutic targets. Furthermore, the identification of novel genetic risk factors may facilitate a better selection of homogeneous subpopulations for therapeutic studies.

\section{Conflict of interest}

The authors declare that there is no conflict of interest.

\section{Acknowledgement}

This research was supported by TÁMOP-4.2.2.A-11/1/KONV2012-0052, the MTA-SZTE Neuroscience Research Group and Hungarian Brain Research Program Grant no. KTIA_13_NAP-A-II/17.

\section{References}

[1] J. Aharon-Peretz, H. Rosenbaum, R. Gershoni-Baruch, Mutations in the glucocerebrosidase gene and Parkinson's disease in Ashkenazi Jews, N. Engl. J. Med. 351 (2004) 1972-1977.

[2] M. Ando, M. Funayama, Y. Li, K. Kashihara, Y. Murakami, N. Ishizu, C. Toyoda, K. Noguchi, T. Hashimoto, N. Nakano, R. Sasaki, Y. Kokubo, S. Kuzuhara, K. Ogaki, C. Yamashita, H. Yoshino, T. Hatano, H. Tomiyama, N. Hattori, VPS35 mutation in Japanese patients with typical Parkinson's disease, Mov. Disord. 27 (2012) 1413-1417.

[3] J.S. Bonifacino, J.H. Hurley, Retromer, Curr. Opin. Cell. Biol. 20 (2008) 427-436.

[4] J. Bras, C. Paisan-Ruiz, R. Guerreiro, M.H. Ribeiro, A. Morgadinho, C. Januario, E. Sidransky, C. Oliveira, A. Singleton, Complete screening for glucocerebrosidase mutations in Parkinson disease patients from Portugal, Neurobiol. Aging 30 (2009) 1515-1517.

[5] K. Brockmann, D. Berg, The significance of GBA for Parkinson's disease, J. Inherit. Metab. Dis. 37 (2014) 643-648.

[6] L.F. Burbulla, R. Kruger, Converging environmental and genetic pathways in the pathogenesis of Parkinson's disease, J. Neurol. Sci. 306 (2011) 1-8.

[7] L.N. Clark, A. Nicolai, S. Afridi, J. Harris, H. Mejia-Santana, L. Strug, L.J. Cote, E.D. Louis, H. Andrews, C. Waters, B. Ford, S. Frucht, S. Fahn, R. Mayeux, R. Ottman, K. Marder, Pilot association study of the beta-glucocerebrosidase N370S allele and Parkinson's disease in subjects of Jewish ethnicity, Mov. Disord. 20 (2005) 100-103.

[8] L.N. Clark, B.M. Ross, Y. Wang, H. Mejia-Santana, J. Harris, E.D. Louis, L.J. Cote, H. Andrews, S. Fahn, C. Waters, B. Ford, S. Frucht, R. Ottman, K. Marder, Mutations in the glucocerebrosidase gene are associated with early-onset Parkinson disease, Neurology 69 (2007) 1270-1277. 
[9] F. Coppede, Genetics and epigenetics of Parkinson's disease, Sci. World J. 2012 (2012) 489830

[10] T.M. Dawson, V.L. Dawson, The role of parkin in familial and sporadic Parkinson's disease, Mov. Disord. 25 (Suppl. 1) (2010) S32-S39.

[11] E.V. De Marco, G. Annesi, P. Tarantino, F.E. Rocca, G. Provenzano, D. Civitelli, I.C. Ciro Candiano, F. Annesi, S. Carrideo, F. Condino, G. Nicoletti, D. Messina, F. Novellino, M. Morelli, A. Quattrone, Glucocerebrosidase gene mutations are associated with Parkinson's disease in southern Italy, Mov. Disord. 23 (2008) 460-463.

[12] H. Deng, K. Gao, J. Jankovic, The VPS35 gene and Parkinson's disease, Mov. Disord. 28 (2013) 569-575.

[13] Z. Gan-Or, N. Giladi, U. Rozovski, C. Shifrin, S. Rosner, T. Gurevich, A. Bar-Shira, A. Orr-Urtreger, Genotype-phenotype correlations between GBA mutations and Parkinson disease risk and onset, Neurology 70 (2008) 2277-2283.

[14] L. Gonzalez-Del Rincon Mde, N. Monroy Jaramillo, A.I. Suarez Martinez, P. Yescas Gomez, M.C. Boll Woehrlen, M. Lopez Lopez, M.E. Alonso Vilatela, The L444P GBA mutation is associated with early-onset Parkinson's disease in Mexican Mestizos, Clin. Genet. 84 (2013) 386-387.

[15] F. Han, D.A. Grimes, F. Li, T. Wang, Z. Yu, N. Song, S. Wu, L. Racacho, D.E. Bulman, Mutations in the glucocerebrosidase gene are common in patients with Parkinson's disease from Eastern Canada, Int. J. Neurosci. (2015) 1-19.

[16] K.S. Hruska, M.E. LaMarca, C.R. Scott, E. Sidransky, Gaucher disease: mutation and polymorphism spectrum in the glucocerebrosidase gene (GBA), Hum. Mutat. 29 (2008) 567-583.

[17] C. Klein, A. Westenberger, Genetics of Parkinson's disease, Cold Spring Harb. Perspect. Med. 2 (2012) a008888.

[18] K.R. Kumar, A. Ramirez, A. Gobel, N. Kresojevic, M. Svetel, K. Lohmann, M.S.C.A. Rolfs, J.R. Mazzulli, R.N. Alcalay, D. Krainc, C. Klein, V. Kostic, A Grunewald, Glucocerebrosidase mutations in a Serbian Parkinson's disease population, Eur. J. Neurol. 20 (2013) 402-405.

[19] K.R. Kumar, A. Weissbach, M. Heldmann, M. Kasten, S. Tunc, C.M. Sue, M. Svetel, V.S. Kostic, J. Segura-Aguilar, A. Ramirez, D.K. Simon, P. Vieregge, T.F. Munte, J. Hagenah, C. Klein, K. Lohmann, Frequency of the D620N mutation in VPS35 in Parkinson disease, Arch. Neurol. 69 (2012) 1360-1364.

[20] S. Lesage, M. Anheim, C. Condroyer, P. Pollak, F. Durif, C. Dupuits, F. Viallet, E. Lohmann, J.C. Corvol, A. Honore, S. Rivaud, M. Vidailhet, A. Durr, A. Brice, Large-scale screening of the Gaucher's disease-related glucocerebrosidase gene in Europeans with Parkinson's disease, Hum. Mol. Genet. 20 (2011) 202-210.

[21] S. Lesage, C. Condroyer, S. Klebe, A. Honore, F. Tison, C. Brefel-Courbon, A. Durr, A. Brice, Identification of VPS35 mutations replicated in French families with Parkinson disease, Neurology 78 (2012) 1449-1450.

[22] S. Lubbe, H.R. Morris, Recent advances in Parkinson's disease genetics, J. Neurol. 261 (2014) 259-266.

[23] X.Y. Mao, J.M. Burgunder, Z.J. Zhang, X.K. An, J.H. Zhang, Y. Yang, T. Li, Y.C. Wang, X.L. Chang, R. Peng, Association between GBA L444P mutation and sporadic Parkinson's disease from Mainland China, Neurosci. Lett. 469 (2010) 256-259.

[24] S.A. Miller, D.D. Dykes, H.F. Polesky, A simple salting out procedure for extracting DNA from human nucleated cells, Nucleic Acids Res. 16 (1988) 1215.

[25] J. Mitsui, I. Mizuta, A. Toyoda, R. Ashida, Y. Takahashi, J. Goto, Y. Fukuda, H. Date, A. Iwata, M. Yamamoto, N. Hattori, M. Murata, T. Toda, S. Tsuji, Mutations for Gaucher disease confer high susceptibility to Parkinson disease, Arch. Neurol. 66 (2009) 571-576.

[26] M. Moraitou, G. Hadjigeorgiou, I. Monopolis, E. Dardiotis, M. Bozi, D. Vassilatis, L. Vilageliu, D. Grinberg, G. Xiromerisiou, L. Stefanis, H. Michelakakis, beta-Glucocerebrosidase gene mutations in two cohorts of Greek patients with sporadic Parkinson's disease, Mol. Genet. Metab. 104 (2011) 149-152

[27] J. Neumann, J. Bras, E. Deas, S.S. O’Sullivan, L. Parkkinen, R.H. Lachmann, A. Li, J. Holton, R. Guerreiro, R. Paudel, B. Segarane, A. Singleton, A. Lees, J. Hardy, H. Houlden, T. Revesz, N.W. Wood, Glucocerebrosidase mutations in clinical and pathologically proven Parkinson's disease, Brain 132 (2009) 1783-1794.

[28] C. Sato, A. Morgan, A.E. Lang, S. Salehi-Rad, T. Kawarai, Y. Meng, P.N. Ray, L.A. Farrer, P. St George-Hyslop, E. Rogaeva, Analysis of the glucocerebrosidase gene in Parkinson's disease, Mov. Disord. 20 (2005) 367-370.

[29] A.H. Schapira, Glucocerebrosidase and Parkinson Rdisease: recent advances, Mol. Cell. Neurosci. 66 (2015) 37-42.

[30] M. Sharma, J.P. Ioannidis, J.O. Aasly, G. Annesi, A. Brice, L. Bertram, M. Bozi, M. Barcikowska, D. Crosiers, C.E. Clarke, M.F. Facheris, M. Farrer, G. Garraux, S. Gispert, G. Auburger, C. Vilarino-Guell, G.M. Hadjigeorgiou, A.A. Hicks, N. Hattori, B.S. Jeon, Z. Jamrozik, A. Krygowska-Wajs, S. Lesage, C.M. Lill, J.J. Lin, T.
Lynch, P. Lichtner, A.E. Lang, C. Libioulle, M. Murata, V. Mok, B. Jasinska-Myga, G.D. Mellick, K.E. Morrison, T. Meitnger, A. Zimprich, G. Opala, P.P. Pramstaller, I. Pichler, S.S. Park, A. Quattrone, E. Rogaeva, O.A. Ross, L. Stefanis, J.D. Stockton, W. Satake, P.A. Silburn, T.M. Strom, J. Theuns, E.K. Tan, T. Toda, H. Tomiyama, R.J. Uitti, C. Van Broeckhoven, K. Wirdefeldt, Z. Wszolek, G. Xiromerisiou, H.S. Yomono, K.C. Yueh, Y. Zhao, T. Gasser, D. Maraganore, R. Kruger, A multi-centre clinico-genetic analysis of the VPS35 gene in Parkinson disease indicates reduced penetrance for disease-associated variants, J. Med. Genet. 49 (2012) 721-726.

[31] U.M. Sheerin, G. Charlesworth, J. Bras, R. Guerreiro, K. Bhatia, T. Foltynie, P. Limousin, L. Silveira-Moriyama, A. Lees, N. Wood, Screening for VPS35 mutations in Parkinson's disease, Neurobiol. Aging 33 (838) (2012) e831-e835.

[32] E. Sidransky, M.A. Nalls, J.O. Aasly, J. Aharon-Peretz, G. Annesi, E.R. Barbosa, A Bar-Shira, D. Berg, J. Bras, A. Brice, C.M. Chen, L.N. Clark, C. Condroyer, E.V. De Marco, A. Durr, M.J. Eblan, S. Fahn, M.J. Farrer, H.C. Fung, Z. Gan-Or, T. Gasser, R. Gershoni-Baruch, N. Giladi, A. Griffith, T. Gurevich, C. Januario, P. Kropp, A.E. Lang, G.J. Lee-Chen, S. Lesage, K. Marder, I.F. Mata, A. Mirelman, J. Mitsui, I. Mizuta, G. Nicoletti, C. Oliveira, R. Ottman, A. Orr-Urtreger, L.V. Pereira, A. Quattrone, E. Rogaeva, A. Rolfs, H. Rosenbaum, R. Rozenberg, A. Samii, T. Samaddar, C. Schulte, M. Sharma, A. Singleton, M. Spitz, E.K. Tan, N. Tayebi, T. Toda, A.R. Troiano, S. Tsuji, M. Wittstock, T.G. Wolfsberg, Y.R. Wu, C.P. Zabetian, Y. Zhao, S.G. Ziegler, Multicenter analysis of glucocerebrosidase mutations in Parkinson's disease, N. Engl. J. Med. 361 (2009) 1651-1661.

[33] S.A. Small, K. Kent, A. Pierce, C. Leung, M.S. Kang, H. Okada, L. Honig, J.P. Vonsattel, T.W. Kim, Model-guided microarray implicates the retromer complex in Alzheimer's disease, Ann. Neurol. 58 (2005) 909-919.

[34] S. Sudhaman, M. Behari, S.T. Govindappa, U.B. Muthane, R.C. Juyal, B.K. Thelma, VPS35 and EIF4G1 mutations are rare in Parkinson's disease among Indians, Neurobiol. Aging 34 (2442) (2013) e2441-e2443.

[35] M. Toft, L. Pielsticker, O.A. Ross, J.O. Aasly, M.J. Farrer, Glucocerebrosidase gene mutations and Parkinson disease in the Norwegian population, Neurology 66 (2006) 415-417.

[36] V. Vacic, L.J. Ozelius, L.N. Clark, A. Bar-Shira, M. Gana-Weisz, T. Gurevich, A. Gusev, M. Kedmi, E.E. Kenny, X. Liu, H. Mejia-Santana, A. Mirelman, D. Raymond, R. Saunders-Pullman, R.J. Desnick, G. Atzmon, E.R. Burns, H. Ostrer, H. Hakonarson, A. Bergman, N. Barzilai, A. Darvasi, I. Peter, S. Guha, T. Lencz, N. Giladi, K. Marder, I. Pe'er, S.B. Bressman, A. Orr-Urtreger, Genome-wide mapping of IBD segments in an Ashkenazi PD cohort identifies associated haplotypes, Hum. Mol. Genet. 23 (2014) 4693-4702.

[37] C. Vilarino-Guell, C. Wider, O.A. Ross, J.C. Dachsel, J.M. Kachergus, S.J. Lincoln, A.I. Soto-Ortolaza, S.A. Cobb, G.J. Wilhoite, J.A. Bacon, B. Behrouz, H.L. Melrose, E. Hentati, A. Puschmann, D.M. Evans, E. Conibear, W.W. Wasserman, J.O. Aasly, P.R. Burkhard, R. Djaldetti, J. Ghika, F. Hentati, A. Krygowska-Wajs, T. Lynch, E. Melamed, A. Rajput, A.H. Rajput, A. Solida, R.M. Wu, R.J. Uitti, Z.K. Wszolek, F. Vingerhoets, M.J. Farrer, VPS35 mutations in Parkinson disease, Am. J. Hum. Genet. 89 (2011) 162-167.

[38] Y. Wang, L. Liu, J. Xiong, X. Zhang, Z. Chen, L. Yu, C. Chen, J. Huang, Z. Zhang, A.A. Mohmed, Z. Lin, N. Xiong, T. Wang, Glucocerebrosidase L444P mutation confers genetic risk for Parkinson's disease in central China, Behav. Brain Funct. 8 (2012) 57.

[39] Y.R. Wu, C.M. Chen, C.Y. Chao, L.S. Ro, R.K. Lyu, K.H. Chang, G.J. Lee-Chen, Glucocerebrosidase gene mutation is a risk factor for early onset of Parkinson disease among Taiwanese, J. Neurol. Neurosurg. Psychiatry 78 (2007) 977-979.

[40] P. Zhang, L. Yu, J. Gao, Q. Fu, F. Dai, Y. Zhao, L. Zheng, S. Zhao, Cloning and characterization of human VPS35 and mouse Vps35 and mapping of VPS35 to human chromosome 16q13-q21, Genomics 70 (2000) 253-257.

[41] X. Zhang, Q.Q. Bao, X.S. Zhuang, S.R. Gan, D. Zhao, Y. Liu, Q. Hu, Y. Chen, F. Zhu, L. Wang, N. Wang, Association of common variants in the glucocerebrosidase gene with high susceptibility to Parkinson's disease among Chinese, Chin. J. Physiol. 55 (2012) 398-404.

[42] A. Zimprich, A. Benet-Pages, W. Struhal, E. Graf, S.H. Eck, M.N. Offman, D. Haubenberger, S. Spielberger, E.C. Schulte, P. Lichtner, S.C. Rossle, N. Klopp, E. Wolf, K. Seppi, W. Pirker, S. Presslauer, B. Mollenhauer, R. Katzenschlager, T. Foki, C. Hotzy, E. Reinthaler, A. Harutyunyan, R. Kralovics, A. Peters, F. Zimprich, T. Brucke, W. Poewe, E. Auff, C. Trenkwalder, B. Rost, G. Ransmayr, J. Winkelmann, T. Meitinger, T.M. Strom, A mutation in VPS35, encoding a subunit of the retromer complex, causes late-onset Parkinson disease, Am. J. Hum. Genet. 89 (2011) 168-175. 